\title{
A Comparative Study of Chinese and Foreign Green Development from the Perspective of Mapping Knowledge Domains
}

\author{
Xingwei $\mathrm{Li}^{1, * \mathbb{D}}$, Jianguo $\mathrm{Du}^{1, * \mathbb{D}}$ and Hongyu Long ${ }^{2}$ \\ 1 School of Management, Jiangsu University, Zhenjiang 212013, China \\ 2 School of Civil Engineering and Architecture, Southwest Petroleum University, Chengdu 610500, China; \\ 201821000820@stu.swpu.edu.cn \\ * Correspondence: 2111710001@stmail.ujs.edu.cn (X.L.); djg@ujs.edu.cn (J.D.); \\ Tel.: +86-18362899102 (X.L.); +86-13656137998 (J.D.)
}

Received: 8 November 2018; Accepted: 21 November 2018; Published: 22 November 2018

\begin{abstract}
This paper identifies the spatial and temporal distribution characteristics, research hotspots, research frontiers and knowledge base of green development research by using the bibliometric method, mapping knowledge domains and spatial analysis method, and through making a comparison of green development research between China and foreign. The main conclusions are as follows: (1) The number of research literature on green development in China and aboard both show a trend of increasing year by year, and the gap of annual volume evolve a M-shaped trend compared with international scholars. The United States and China are both major countries in green development research, and their international academic cooperation is relatively close. Moreover, the main research findings are concentrated in the northern hemisphere while there is less distribution in the southern hemisphere, and the eastern and western hemispheres are distributed widely. (2) The research hotspots of China's green development mainly include development concepts, regional and urban development and ecological environment while international green development mainly include green economy, framework, city and supply chain management. (3) The frontiers of China's green development research are focused on coordinated development, ecological environment and green development concepts while international green development research are more abundant. (4) The knowledge base of the research includes Manuscript of Economics and Philosophy in 1844, the concept of sustainable development and the theory of two mountains.
\end{abstract}

Keywords: green development; mapping knowledge domains; CiteSpace; document co-citation; scientific metrology; geographic information system (GIS)

\section{Introduction}

From the color itself, you can get green by superimposing blue and yellow in the three primary colors. In nature, most of the plants are also green in color. Therefore, the meaning of green is often associated with concepts, such as nature and ecology.

With the development of productivity and social economy, green has been given the meaning of environmental protection. e.g., green agriculture (GA), green building (GB), green construction (GC), green consumption (GC), green energy sources (GES), green food (GF), green manufacturing $(\mathrm{GM})$, green travel (GT), etc. It can be seen that green is not only a necessary condition for sustainable development, but also an important embodiment of the people's pursuit of a better life.

At present, some scholars have analyzed green development from the perspective of influencing factors and industries [1,2]. Despite some scholars have carried out some exploratory research on 
green development, forming a consensus that it is necessary to study green development, the current academic research on green development has not yet formed a conclusion, so the study is still in the exploratory stage. As a member of the developing countries, China's green development is worthy of the world's attention. And it is of great value to compare the research on green development between Chinese and foreign. This paper reveals some of the characteristics of green development theory by deeply mining the information about green development research papers. First, the quantitative trends of published papers can more intuitively reflect whether the research topic continues to be concerned by researchers. By comparing the number of published papers on green development in China and other countries, it can be determined whether the topic continues to attract people's attention and whether there is value for further research in the future. Second, the geographical distribution of the research topic can more intuitively reflect how the areas of concern for the topic are distributed. Through the study of spatial and temporal distribution characteristics of green development research, this paper reveals the regional distribution characteristics of the research to find out where the achievements are more prominent. Third, this paper explores the main supporting disciplines and institutions of green development research by researching the distribution characteristics of journals and institutions. In addition, we hope to provide new researchers with information on green development to find important references and applications. First, CiteSpace was used to conduct in-depth research on green development, providing new ideas about the study of green development. Second, the research hotspot analysis can reveal the main focus areas of green development, making the theoretical focus on green development research clearer. Third, frontier analysis can provide researchers with up-to-date information on green development research and provide valuable information or references for their potential research areas. Fourth, through the knowledge base research on green development, this paper reveals the widely accepted classical theory and knowledge information on this field.

Therefore, our research has theoretical and practical significance in this field. (1) Theoretical significance: (1) Broaden and deepen the theoretical research of mapping knowledge domains; (2) Enrich the theoretical study of sustainable development; (3) Consummate and comb the theoretical research of green development; (2) Realistic meaning: (1) Research conclusions are useful to help people pay attention to some green development issues in people's lives and production; (2) The conclusions of the study are meaningful to help the topic selection of the relevant journals; (3) The conclusions of the study will help institutions in different regions to pay more attention to green development issues; (4) Research conclusions can provide reference to government departments to develop guiding strategies.

This paper is mainly to solve the following problems:

Q1: What are the spatial and temporal distribution characteristics of Chinese and international scholars in the study of green development?

Q2: What are the research hotspots?

Q3: What are the frontiers of research?

Q4: What is the basis of research knowledge?

In order to solve the above problems and clarify the research context of scholars at home and abroad on green development, this paper mainly carried out the following research contents:

This paper emphatically analyze China's and international green development research from four aspects: Temporal and spatial distribution characteristics, research hotspots, research frontiers and research knowledge base based on the bibliometric method, mapping knowledge domains and spatial analysis method, using CiteSpace 5.2.R2, a scientific text mining and visualization software, to carry out visualization analysis of co-operation network, co-occurrence network and co-citation on 364 Chinese documents with their citations published in the CSSCI database (1999-2017) and 1015 English documents with their citations recorded in the SSCI and SCI databases (2000-2017) (e.g., visual analysis of cooperative networks, co-occurrence networks, and co-cited cases). 
(1) In the part of temporal and spatial distribution, this paper mainly used Excel software to statistically analyze the distribution of relevant literature publications, obtaining the characteristics of the age distribution of green development research volume. By using CiteSpace 5.2.R2 to conduct cooperative network analysis (including cooperative country network analysis, cooperative organization network analysis, cooperative author network analysis) and journal co-citation analysis, applying Arc GIS software to plot the results of the cooperative country network analysis, and utilizing Excel software to analyze the distribution of journals according to the volume of relevant literature, the spatial distribution characteristics of the volume of green development research are obtained; (2) In the part of research hotspots, this paper used CiteSpace 5.2.R2 to carry out analysis of keywords co-occurrence, keywords co-occurrence cluster-based and keywords co-occurrence timezone evolution, and obtained green development research hotspots; (3) In the frontier part of the research, this paper used CiteSpace 5.2.R2 to test the relevant literature for keywords burst and obtained the frontier of green development research; (4) In the part of the knowledge base, this paper used CiteSpace 5.2.R2 to analyze the co-citation of relevant literature and obtained the knowledge base of green development research. Ultimately, this paper shows us the spatial and temporal distribution, hotspots, frontiers and knowledge base of green development research at home and abroad, and provide the basis for future green development research.

\section{Literature Review}

Liu divided the development and evolution process of international green thoughts into the following three stages from the perspective of the evolution of thoughts: The 1960s-1970s was the first green trend of thought, during which the main idea was to reflect on the economic growth and strengthen the dominant idea of end-of-pipe governance. During the 1980s and 1990s, it was the second green trend of thought. During this period, it was dominated by weak sustainable development and improving resource and environmental efficiency. It is the third green trend of thought since the beginning of this century. During this period, the strong sustainable development of green economy and global governance was the dominant idea [3]. To achieve the goal of green development, it is necessary to ultimately implement it from thoughts to human behaviors. From the psychological point of view, human behavior is generally generated by the mechanism of "need $\rightarrow$ demand $\rightarrow$ motivation $\rightarrow$ behavior" [4]. Another point of view in psychology is that human behavior is the result of the dual role of the subject and the environment [5]. Therefore, it is easy to find out that human green behavior should be closely related to the environment from the perspective of psychology. And the green behavior mechanism of people should be: Green development need $\rightarrow$ green development demand $\rightarrow$ green development motivation $\rightarrow$ green behavior.

Facing the enormous environmental pressure faced by China's economic development, Wang et al. proposed that to realize the green transformation of China's economic development, it is necessary to formulate the concept of national green development strategic planning [6]. Yang et al. established a green development indicator system by analyzing the relationship between the green development index and the level of economic development [7]. The above two research teams were early research teams for green development in the Chinese academic community and have made important contributions to China's green development research.

The Fifth Plenary Session of the Eighteenth Central Committee of the Communist Party of China and the Proposal of the Central Committee of the Communist Party of China on the Formulation of the Thirteenth Five-Year Plan for National Economic and Social Development, adopted in 2015, put forward the theory of green development and elevated it to the height of the national development strategy, which together with the four development concepts of innovation, coordination, openness and sharing, constituted the five major development concepts guiding China's economic and social development in the future [8] In 2016, General Secretary Xi Jinping delivered a keynote speech on green development at the opening ceremony of the G20 Business Summit, emphasizing that lucid waters and lush mountains are invaluable assets, and improving the environment are equal to developing 
productivity [9]. General Secretary Xi Jinping pointed out in the report of the 19th National Congress of the Communist Party of China in 2017: Adhering to the harmonious symbiosis between man and nature is one of the ideas and basic strategies of socialism with Chinese characteristics in the new era. Human and nature are communities of life. Mankind must respect nature, conform to nature, protect nature, promote green development and form a green development model [10]. The promotion of green development in the new era has certain theoretical significance: Deepening understanding of Marxist ecological thoughts, enriching and developing the Marxist concept of development and deepening the development of the theory of socialist ecological civilization construction with Chinese characteristics. The promotion of green development in the new era has certain practical significance: Considering nature and development equally important and integrating green development theory into society will contribute to the healthy and sustainable development of Chinese society and have great significance for realizing a socialist harmonious society. In March 2018, China carried out institutional reforms of the State Council, and the State Council departments of the Ministry of Ecology and Environment and the Ministry of Natural Resources are closely related to green development. It can be seen that the Chinese party and government departments, as well as the academic and real industries, attach great importance to green development.

It is undeniable that development is the prerequisite for all human activities, whether it is China or foreign countries. Faced with a series of survival crises brought about by climate change and environmental pollution, human beings began to face up to the relationship between economic development and the natural environment [11]. In order to create a green and low-carbon economic development environment, green development, such as green economy [12-14], green building [15-17] and green supply chain $[18,19]$ have received high attention from international researchers, which shows that green development is suitable in line with the trend. This shows that green development is in line with the trend, and this development is sustainable. However, extensive reading of papers on green development in China and abroad shows following characteristics: The research scope is wide, involving a wide range of industries and disciplines, which reveals that, due to the advanced nature of green development, it has been highly recognized by researchers. In summary, it is an urgent matter to sort out the achievements of research on green development in China and abroad.

\section{Method and Data Sources}

\subsection{Method}

The research methods used in this paper are the bibliometric method, and the mapping knowledge domains and spatial analysis method. Bibliometrics is a method of statistical analysis originating in the early 20th century, which is used to study quantitative research on literature [20]. Bibliometrics is a statistical method used to assess and quantify the growth trends of a particular topic. It is widely used in scientific research in various disciplines [21,22]. Therefore, this paper mainly uses the bibliometric method to study the age distribution characteristics of China and international green development research. The mapping knowledge domains can perform visual analysis of a certain research field, which is realized by data mining, scientific measurement, information analysis and drawing [23]. CiteSpace is a visual analysis software developed by Professor Chen from Drexel University in the United States based on the Java language, which has been iteratively updated to version 5.2.R2 [24]. At present, many researchers use Citespace software to conduct mapping knowledge domains research, and have achieved good results [25-28]. This paper uses CiteSpace5.2.R2 software to visualize the cooperative network, co-occurrence network and co-cited cases, obtaining relevant mapping knowledge domains. The spatial analysis method is a quantitative research method for geospatial phenomena; and is the core of GIS [29]. In this paper, Arc GIS software is used to extract data from the knowledge map of the green development research cooperation network of the major countries, and then the visual images of the distribution volume zoning of the green development research cooperation network of the major countries are obtained. 


\subsection{Data Sources}

The data in this paper is divided into two categories: Chinese and international data. First, the periodical literature collected in CSSCI database is used as the data source of China. 364 Chinese papers related to green development were published in 1999-2017 by a topic search using the term "green development" (checking "exact" option), besides, the document type was selected as "article". Then, Web of Science is used as the international data source, 1336 international papers related to green development were published in 1986-2018 by a topic search using the term "green development", besides, SCI-EXPANDED and SSCI were used as citation indexes to make the papers more comprehensive. Subsequently, ARTICLE was selected in the document type area, and after clicking the option to refine, the results were retrieved from 1015 English documents published from 2000 to 2017. Figure 1 shows the specific search steps.

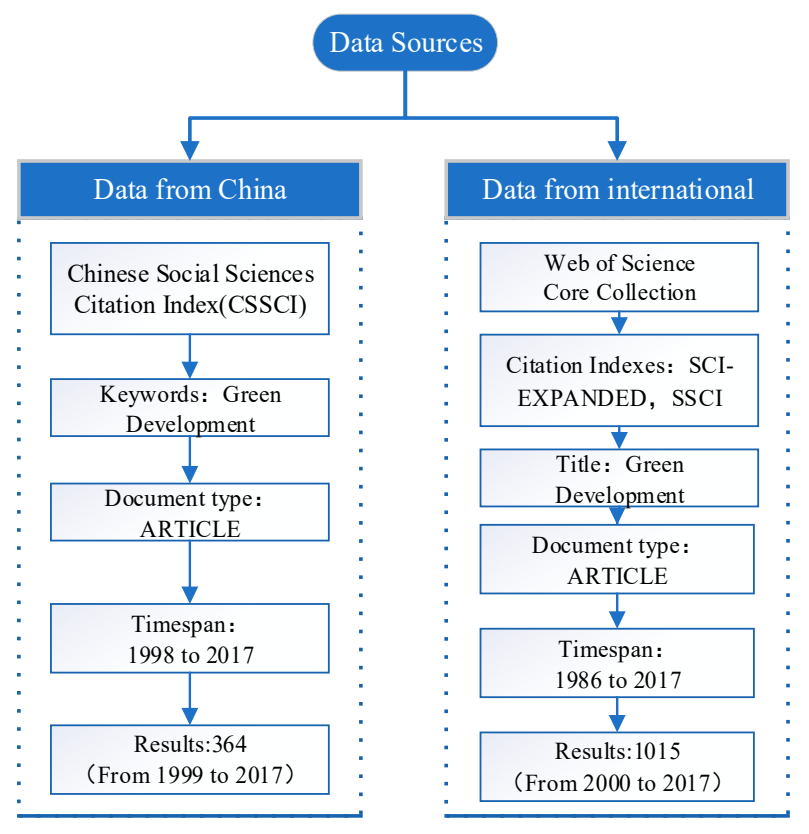

Figure 1. Retrieval procedure of research data.

\subsection{Data Processing}

First, the processing of Chinese data was carried out in this paper. Since CiteSpace 5.2.R2 cannot directly identify and analyze the data downloaded by CSSCI, it needs to be formatted before entering the next analysis. Therefore, 364 Chinese literature samples were converted by the conversion function "Data $\rightarrow$ import/export" of CiteSpace 5.2. R2. Several restrictions were set that the time span was set from 1999 to 2017 and the time zone was set to 1. Besides, the corresponding other settings were selected according to different research questions. Then, the processing of international data was carried out. In order to de-duplicate the data and divide the data according to the time, the 1015 English documents were firstly de-duplicated by the de-duplication function of CiteSpace 5.2.R2. Several restrictions were set that the time span was set from 2000 to 2017 and the time zone was set to 1. Besides, the corresponding other settings were selected according to different research questions.

\section{Results and Analysis}

\subsection{Time Distribution}

After statistical processing of the data, it is found that in recent years, both Chinese and international scholars' research literature on green development shows an increasing trend year by year. (Figure 2). 


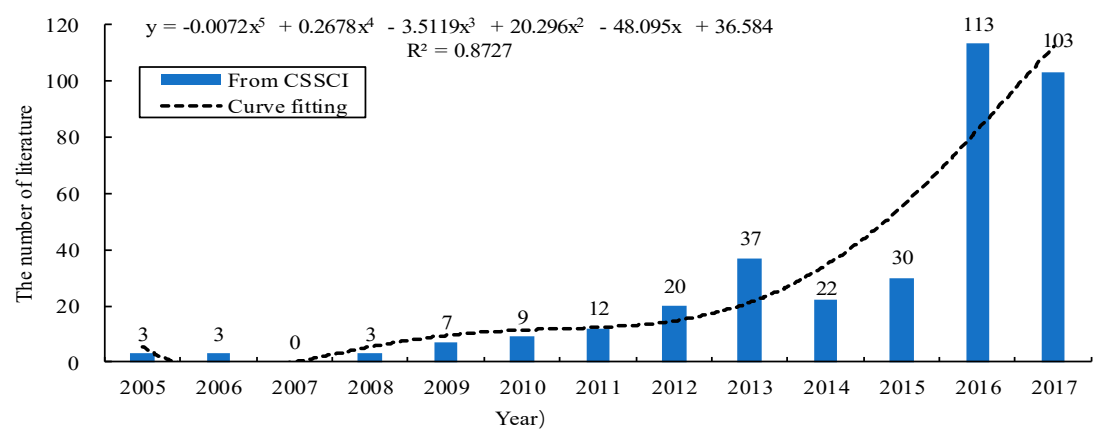

(a)

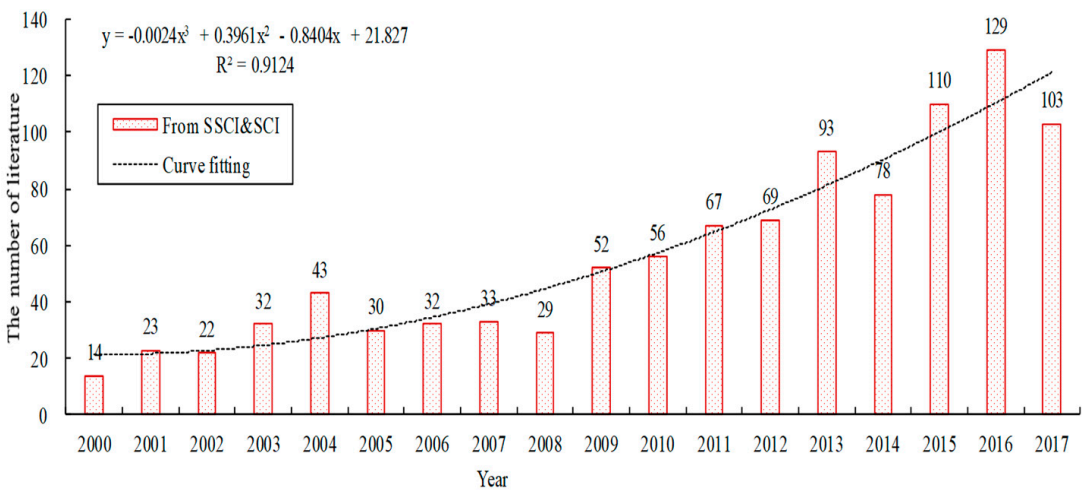

(b)

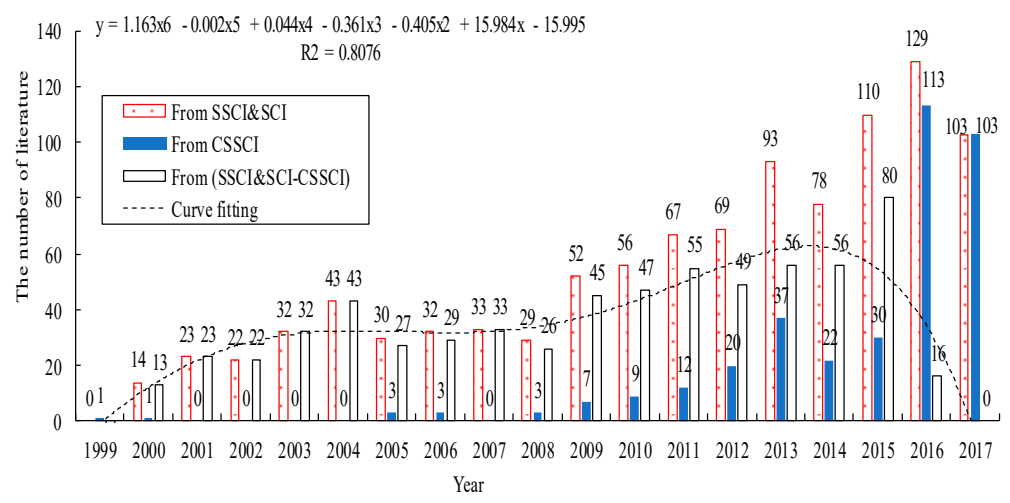

(c)

Figure 2. Chronological distribution of published volume. (a) The volume and trend of Chinese scholars on green development research; (b) the volume and trend of international scholars on green development research; (c) the quantitative gap and trend of literature on green development research between Chinese and international scholars.

The trend of chronological distribution of papers related to green development in CSSCI database can be expressed by Formula (1) as follows:

$$
\begin{aligned}
& y=-0.0072 x^{5}+0.2678 x^{4}-3.5119 x^{3}+20.296 x^{2}-48.095 x+36.584 \\
& R^{2}=0.8727
\end{aligned}
$$

where $y$ indicates the number of publications (pieces) and $x$ indicates the time of publication (years). $R^{2}$ equals 0.8727 , indicating a good degree of fit. According to this trend (Figure $2 \mathrm{a}$ ), it can be seen that the research literature on green development of Chinese scholars shows a trend of increasing year by year. 
The chronological distribution trend of papers published in SCI-EXPANDED and SSCI citation indexes related to green development in the Web of Science Core Collection can be expressed by Formula (2) as follows:

$$
\begin{aligned}
& y=-0.024 x^{3}+0.3961 x^{2}-0.8404 x+21.827 \\
& R^{2}=0.9124
\end{aligned}
$$

where $y$ indicates the number of publications (pieces) and $x$ indicates the time of publication (years). $R^{2}$ equals 0.9124 , indicating a good degree of fit. According to this trend (Figure 2b), it can be seen that the research literature on green development of international scholars shows a trend of increasing year by year.

In order to grasp more clearly the gap and trend between Chinese scholars and international scholars in the number of papers on green development published each year, the gap is expressed by subtracting the number of SSCI and SCI papers from the number of CSSCI papers. The chronological distribution trend of the gap can be expressed by Formula (3) as follows:

$$
\begin{aligned}
& y=1.163 x^{6}-0.002 x^{5}+0.044 x^{4}-0.361 x^{3}-0.405 x^{2}+15.984 x-15.995, \\
& R^{2}=0.8076
\end{aligned}
$$

where $y$ indicates the number of publications (pieces) and $x$ indicates the time of publication (years). $R^{2}$ equals 0.8076 , indicating a good degree of fit. Although the number of Chinese scholars' research literature on green development in the years before 2017 lags behind that of international scholars, the gap has narrowed significantly since 2016, until 2017, the gap shows zero. Moreover, according to this trend (Figure 2c), it can be seen that the gap between Chinese and international scholars in the number of published documents on green development shows an M-shaped evolution trend. In the future, the number of Chinese scholars' research papers on green development will exceed that of international scholars.

\subsection{Spatial Distribution}

\subsubsection{Research Cooperation Network}

In order to clearly grasp the cooperation distribution of green development research in major countries, this paper processed 1015 international data through the cooperative network analysis function of CiteSpace 5.2.R2, and obtained the cooperation distribution of major countries and regions of green development research. According to the number of papers issued by different countries, the zoning map is drawn according to six grades of $<5,5 \sim 10,10 \sim 15,15 \sim 20,20 \sim 38$, and $\geq 38$ by Arc GIS software, and the data of the zoning map are presented as tables. (Figure 3, Tables 1 and 2).

Table 1. An overview of the top 10 countries ranking by published volume.

\begin{tabular}{ccc}
\hline Country & The Number of Literature & Center Degree \\
\hline United States & 218 & 0.17 \\
China & 137 & 0.14 \\
India & 85 & 0.07 \\
Japan & 85 & 0.06 \\
United Kingdom & 53 & 0.06 \\
Australia & 38 & 0.02 \\
Germany & 38 & 0.06 \\
Spain & 34 & 0.03 \\
Canada & 32 & 0.04 \\
Brazil & 29 & 0.04 \\
\hline
\end{tabular}


Table 2. Regional distribution of the published volume in major countries.

\begin{tabular}{cccccc}
\hline $\begin{array}{c}\text { Hemisphere } \\
\text { Position }\end{array}$ & Country & $\begin{array}{c}\text { The Number } \\
\text { of Literature }\end{array}$ & $\begin{array}{c}\text { Hemisphere } \\
\text { Position }\end{array}$ & Country & $\begin{array}{c}\text { The Number } \\
\text { of Literature }\end{array}$ \\
\hline northwest & United States & $\geq 21$ & northeast & Portugal & $5 \sim 10$ \\
northeast & China & $\geq 21$ & southeast & South Africa & $5 \sim 10$ \\
northeast & Japan & $\geq 21$ & northeast & Denmark & $5 \sim 10$ \\
northeast & India & $\geq 21$ & northeast & Singapore & $5 \sim 10$ \\
northeast & United Kingdom & $\geq 21$ & northeast & Egypt & $5 \sim 10$ \\
southeast & Australia & $\geq 21$ & northeast & Belgium & $<5$ \\
northeast & Germany & $\geq 21$ & northeast & Switzerland & $<5$ \\
northeast & Spain & $\geq 21$ & northwest & Scotland & $<5$ \\
northwest & Canada & $\geq 21$ & northeast & Thailand & $<5$ \\
southwest & Brazil & $\geq 21$ & northeast & Czech Republic & $<5$ \\
northeast & Italy & $16 \sim 20$ & northeast & Poland & $<5$ \\
northeast & Iran & $16 \sim 20$ & northeast & Saudi Arabia & $<5$ \\
northeast & Korea & $16 \sim 20$ & northwest & Mexico & $<5$ \\
northeast & France & $16 \sim 20$ & northeast & Vietnam & $<5$ \\
northwest & Turkey & $16 \sim 20$ & northeast & Austria & $<5$ \\
northeast & Sweden & $11 \sim 15$ & northeast & Pakistan & $<5$ \\
northeast & Malaysia & $11 \sim 15$ & northeast & Finland & $<5$ \\
northeast & Netherlands & $11 \sim 15$ & northeast & Israel & $<5$ \\
northeast & Greece & $5 \sim 10$ & northeast & Oman & $<5$ \\
\hline
\end{tabular}

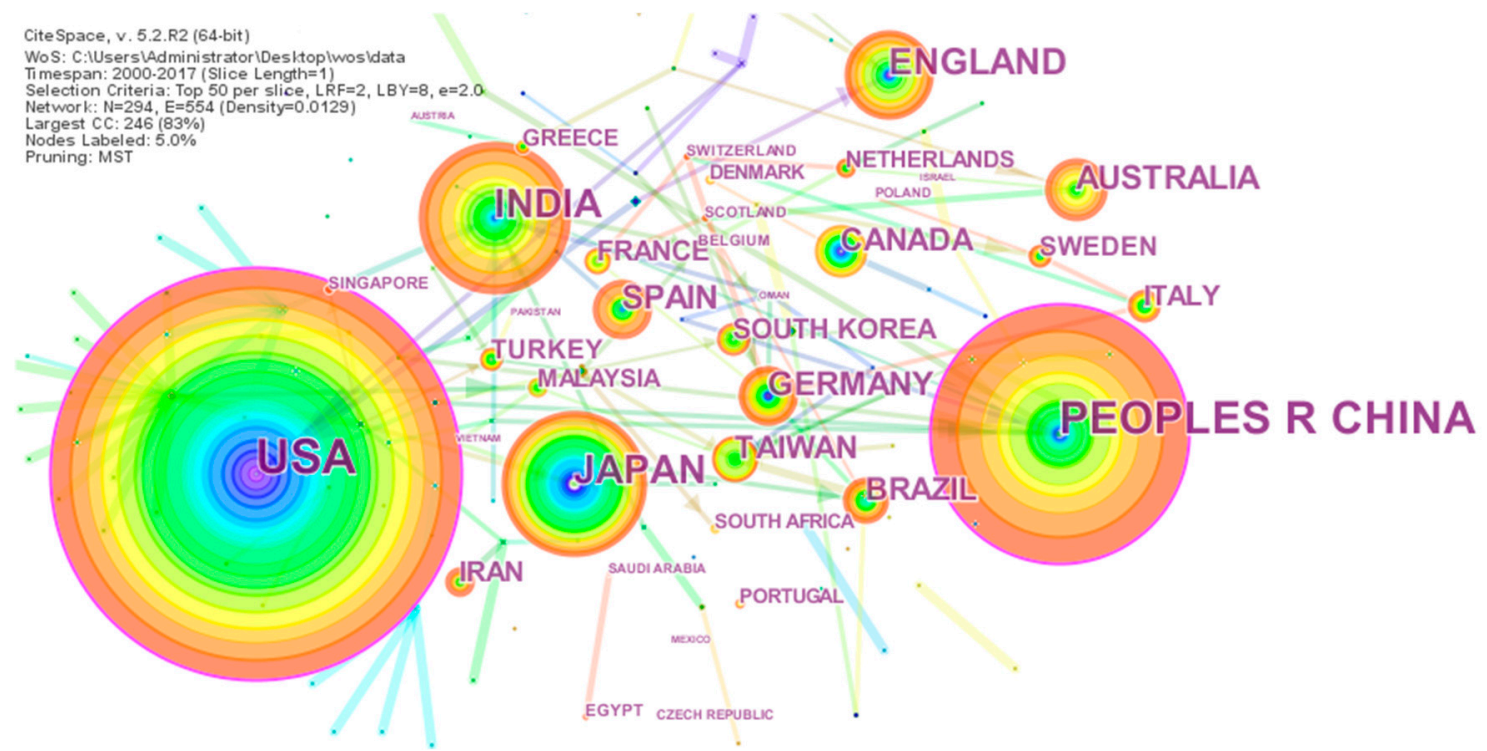

Figure 3. Countries distribution of authors according to the total number of publications.

According to the visualization results, it can be seen that the node centers of the United States and China occupy the first (centrality 0.17 ) and the second (centrality 0.14 ) respectively, indicating that the United States and China are both major countries in green development research. Both are closely cooperating with most countries or scientific research institutions in the cooperation network. It is worth noting that although the results show that the United States and China are far ahead of the rest in the field of green development research, the number of articles published by China in this field by SSCI and SCI is 137 (62.84\% of the US), indicating that there is still room for Chinese scholars to improve the number of their studies on green development in the international academic community. The eight countries following China are: India (centrality 0.07), Japan (centrality 0.06), United Kingdom (centrality 0.06), Australia (centrality 0.02), Germany (centrality 0.06), and Spain (centrality 0.03), Canada (centrality 0.04) and Brazil (centrality 0.04).

Table 2 shows the spatial distribution characteristics of the green development research in each country. From the north-south perspective, the green development research results are mainly 
concentrated in the northern hemisphere countries, while the southern hemisphere countries are less distributed. From the east-west perspective, the results of green development research are widely distributed in the eastern and western hemispheres. In the western hemisphere countries and regions, the results of green development research are mainly concentrated in the United States, while in the eastern hemisphere countries and regions, the results of green development research are mainly concentrated in China, India, Japan, the United Kingdom, Australia, and Germany.

In order to clearly grasp the distribution of cooperation institutions and authors of green development research, 364 Chinese data and 1015 international data were processed through the cooperative network analysis function of CiteSpace 5.2.R2 to obtain the distribution of cooperation institutions (Figure 4) and co-authors (Figure 5) in green development research.

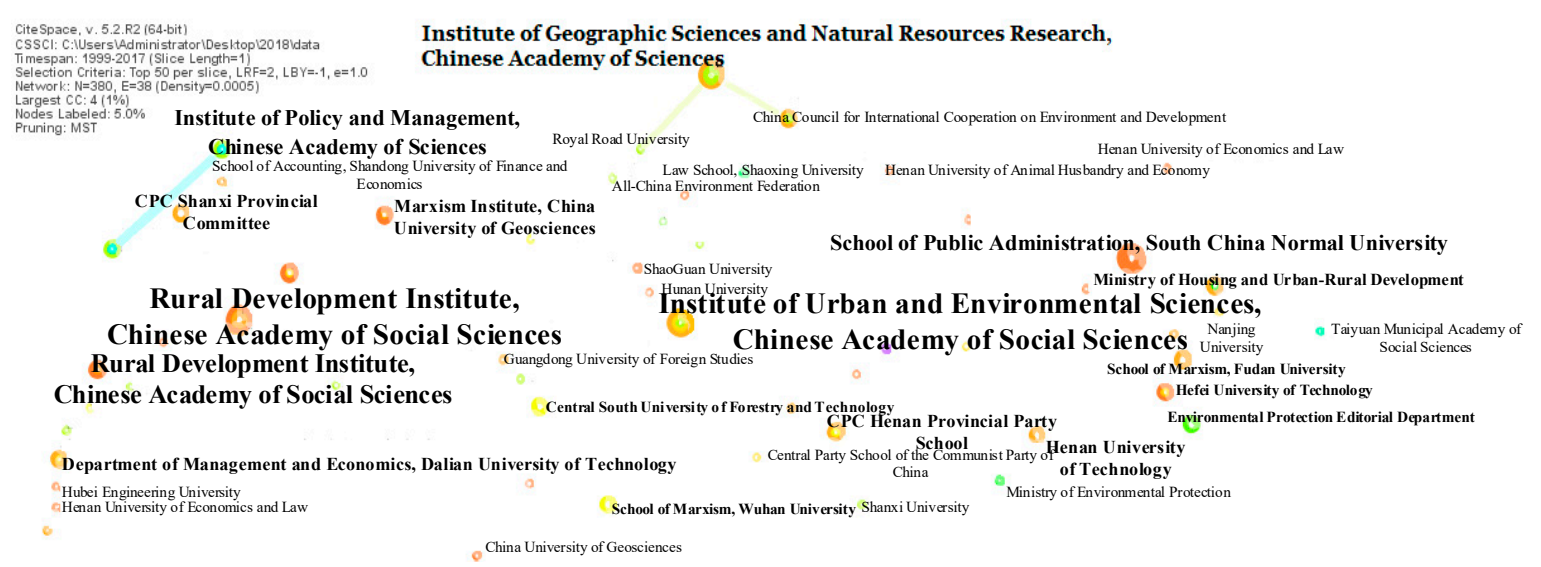

(a)

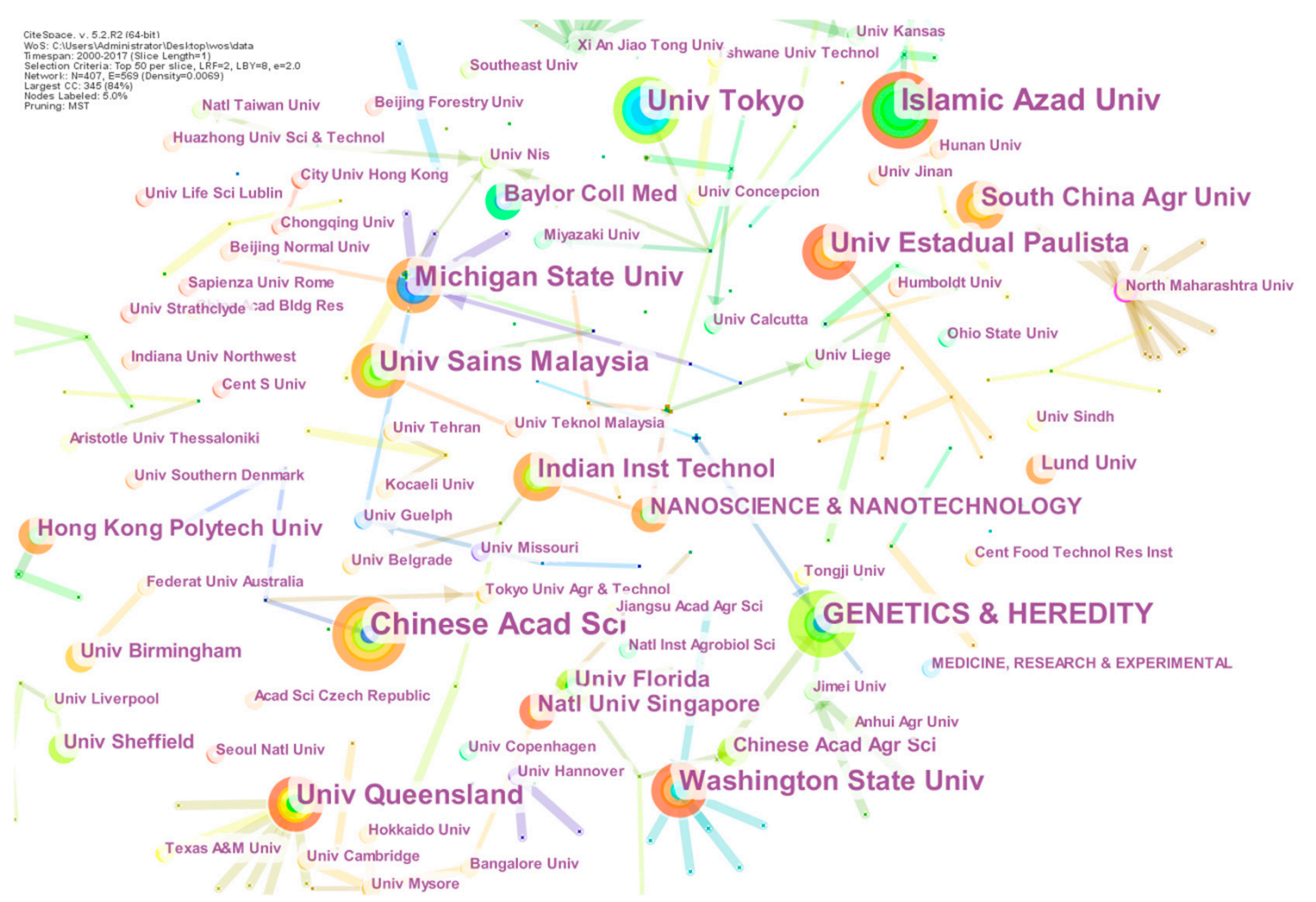

(b)

Figure 4. Network of institutes and the strongest collaborations among them. (a) Network of institutes and the strongest collaborations among them in China; (b) network of institutes and the strongest collaborations among them in international. 


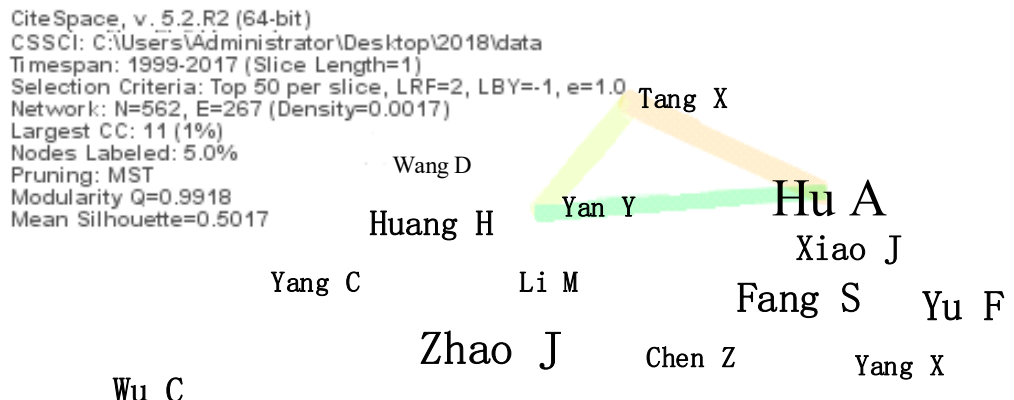

Xu X

Yue $\mathrm{S}$

Zhu Huang J
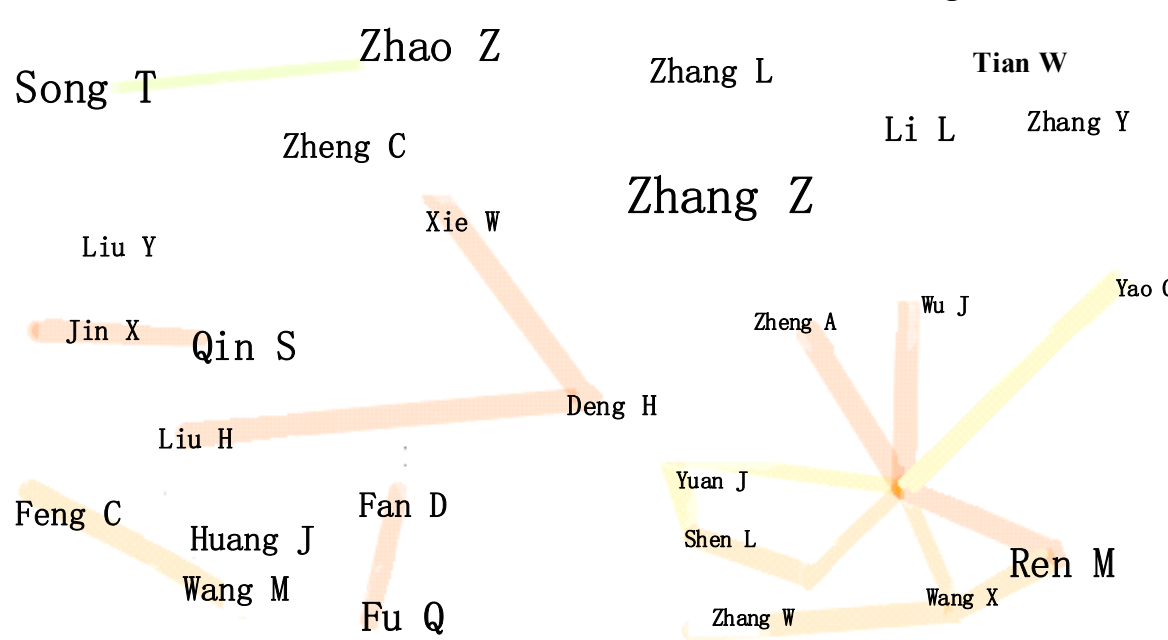

(a)

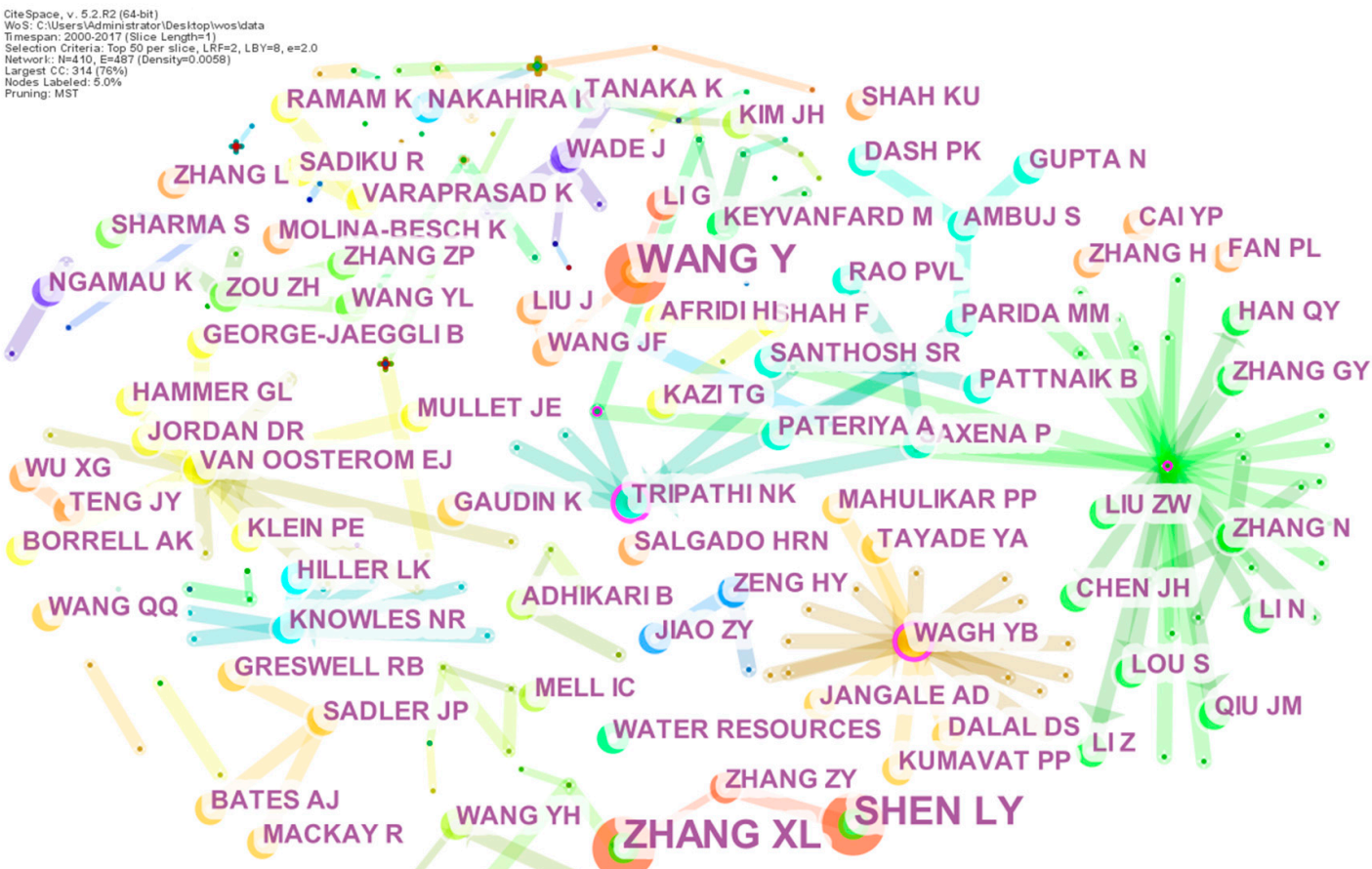

(b)

Figure 5. Network of co-authors and the strongest collaborations among them. (a) Network of co-authors and the strongest collaborations among them in China; (b) network of co-authors and the strongest collaborations among them in international. 
China's research institutions on green development research mainly come from party and government departments, magazines, research institutes, ordinary higher education institutions and party schools. The main party and government departments include the Ministry of Housing and Urban-Rural Development, the CPC Jiangxi Provincial Committee, etc.; Major magazines include Environmental Protection Magazines, etc.; The main research institutes include the Institute of Urban Development and Environment of the Chinese Academy of Social Sciences, the Institute of Rural Development of the Chinese Academy of Social Sciences, the Institute of Geographic Sciences and Natural Resources of the Chinese Academy of Sciences, the China Social Science Evaluation Center of the Chinese Academy of Social Sciences, and the Institute of Science, Policy and Management of the Chinese Academy of Sciences; The main institutions of higher learning include the School of Public Administration of South China Normal University, the Department of Social Sciences of Central South University of Forestry and Technology, the School of Marxism of China University of Geosciences, the School of Marxism of Wuhan University, the University of Hefei, the School of Marxism of Fudan University, and the School of Marxism of Central South University of Forestry and Technology, Department of Management and Economics, Dalian University of Technology, Henan University of Technology; The main party schools include the Party School of the CPC Henan Provincial Committee.

China's scientific research teams on green development research mainly center on Hu A., Huang Z., Zhang Z., Qin S., Li L., Zhao J., Feng C., Zhao W., Huang J., Liu S., Huang J., Fan D., etc.

The international research institutions on green development research mainly come from research institutes and ordinary higher education institutions. The main research institutes include the Chinese Academy of Sciences and the Chinese Academy of Agricultural Sciences; The main institutions of higher learning include Iranian Islamic Azad University, Tokyo University of Japan, University of Queensland, Michigan State University, Washington State University, Baylor College of Medicine, Sao Paulo State University of Brazil, University of Malaysia, Indian Institute of Technology, South China Agricultural University Hong Kong Polytechnic University, National University of Singapore, University of Birmingham, UK, University of Sheffield, UK and Lund University, Sweden. From the visualization results of cooperation among international scientific research institutions, it can be seen that Chinese scientific research institutions have actively participated in international academic cooperation in green development research. Among them, the Chinese Academy of Sciences, the Chinese Academy of Agricultural Sciences, the South China Agricultural University and the Hong Kong Polytechnic University and other Chinese scientific research institutions performed outstandingly.

International research teams on green development research mainly center on Wang, Shen, Zhang, Liu, Hilker, Jiao, Sadiku, Kim, Hammer, Tayade, Zhao, Arakawa and Pradhan.

\subsubsection{Distribution of Published Journals}

In order to clearly grasp the distribution of the published journals of the green development research, 364 Chinese and 1015 international samples were processed through the cooperative network analysis function of CiteSpace 5.2.R2, obtaining the distribution of the co-cited journals in the green development study (Figure 6, Tables 3-6).

Table 3. Journals citation ranked top 10 in China (Frequency).

\begin{tabular}{ccc}
\hline Frequency & Center Degree & Journal \\
\hline 64 & 0.04 & China Population, Resources and Environment \\
34 & 0.05 & Economic Research Journal \\
32 & 0.11 & China Industrial Economics \\
23 & 0.04 & Economic Geography \\
22 & 0.03 & Management World \\
20 & 0.1 & China Soft Science \\
20 & 0.06 & Social Science in China \\
20 & 0 & Ecological Economics \\
19 & 0.06 & Geographical Research \\
18 & 0.05 & Environmental Protection \\
\hline
\end{tabular}


Table 4. Journals citation ranked top 10 in China (Centrality).

\begin{tabular}{ccc}
\hline Frequency & Center Degree & Journal \\
\hline 2 & 0.18 & International Economics and Economic Policy \\
32 & 0.11 & Chinese Industrial Economics \\
20 & 0.1 & China Soft Science \\
1 & 0.08 & Environmental Innovation and Societal Transitions \\
1 & 0.08 & Journal of Common Market Studies \\
13 & 0.07 & Acta Ecologica Sinica \\
6 & 0.07 & Environmental Economy \\
1 & 0.07 & Journal of Financial Economies \\
20 & 0.06 & Social Science in China \\
19 & 0.06 & Geographical Research \\
\hline
\end{tabular}

Table 5. Journals citation ranked top 10 in International (Frequency).

\begin{tabular}{ccc}
\hline Frequency & Center Degree & Journal \\
\hline 619 & 0 & CW \\
164 & 0.37 & SCIENCE \\
130 & 0.19 & P NATL ACAD SCI USA \\
125 & 0.17 & NATURE \\
89 & 0.04 & J AGR FOOD CHEM \\
82 & 0.08 & J CLEAN PROD \\
68 & 0.07 & ANAL CHIM ACTA \\
62 & 0.18 & ENVIRON SCI TECHNOL \\
61 & 0.01 & J CHROMATOGR A \\
60 & 0.02 & GREEN CHEM \\
\hline
\end{tabular}

Table 6. Journals citation ranked top 10 in International (Centrality).

\begin{tabular}{ccc}
\hline Frequency & Center Degree & Journal \\
\hline 164 & 0.37 & SCIENCE \\
46 & 0.21 & PLANT PHYSIOL \\
130 & 0.19 & P NATL ACAD SCI USA \\
62 & 0.18 & ENVIRON SCI TECHNOL \\
125 & 0.17 & NATURE \\
10 & 0.16 & COPEIA \\
31 & 0.15 & J APPL POLYM SCI \\
48 & 0.14 & J ENVIRON MANAGE \\
9 & 0.14 & BIOSCIENCE \\
21 & 0.13 & SCI TOTAL ENVIRON \\
\hline
\end{tabular}

According to the degree of co-citation, the most frequently cited journals in China are the environmental, geographical, economic and management journals, such as "China Population, Resources and Environment", "Economic Research Journal", "China Industrial Economics", "Economic Geography", "Management World", "China Soft Science", "Social Science in China", "Ecological Economics", "Geographical Research", "Environmental Protection", among which the three most central Chinese journals are "China industrial economics", "China Soft Science" and "Acta Ecologica Sinica". However, the most central journal is not a Chinese journal, but "International Economics and Economic Policy". The remaining 10 Chinese journals ranked in the top 10 are "Environmental Economics", "Social Science in China", and "Geographical Research". In addition, the remaining 10 English journals ranked in the center are "Environmental Innovation and Societal Transitions", "Journal of Common Market Studies" and "Journal of Financial Economies". The most popular journals in international green development research are "CW", "SCIENCE", "P NATL ACAD SCI USA", "NATURE", "J AGR FOOD CHEM", "J CLEAN PROD", "ANAL CHIM ACTA", "ENVIRON SCI TECHNOL", "J CHROMATOGR A", "GREEN CHEM" and other SSCI, SCI journals. 


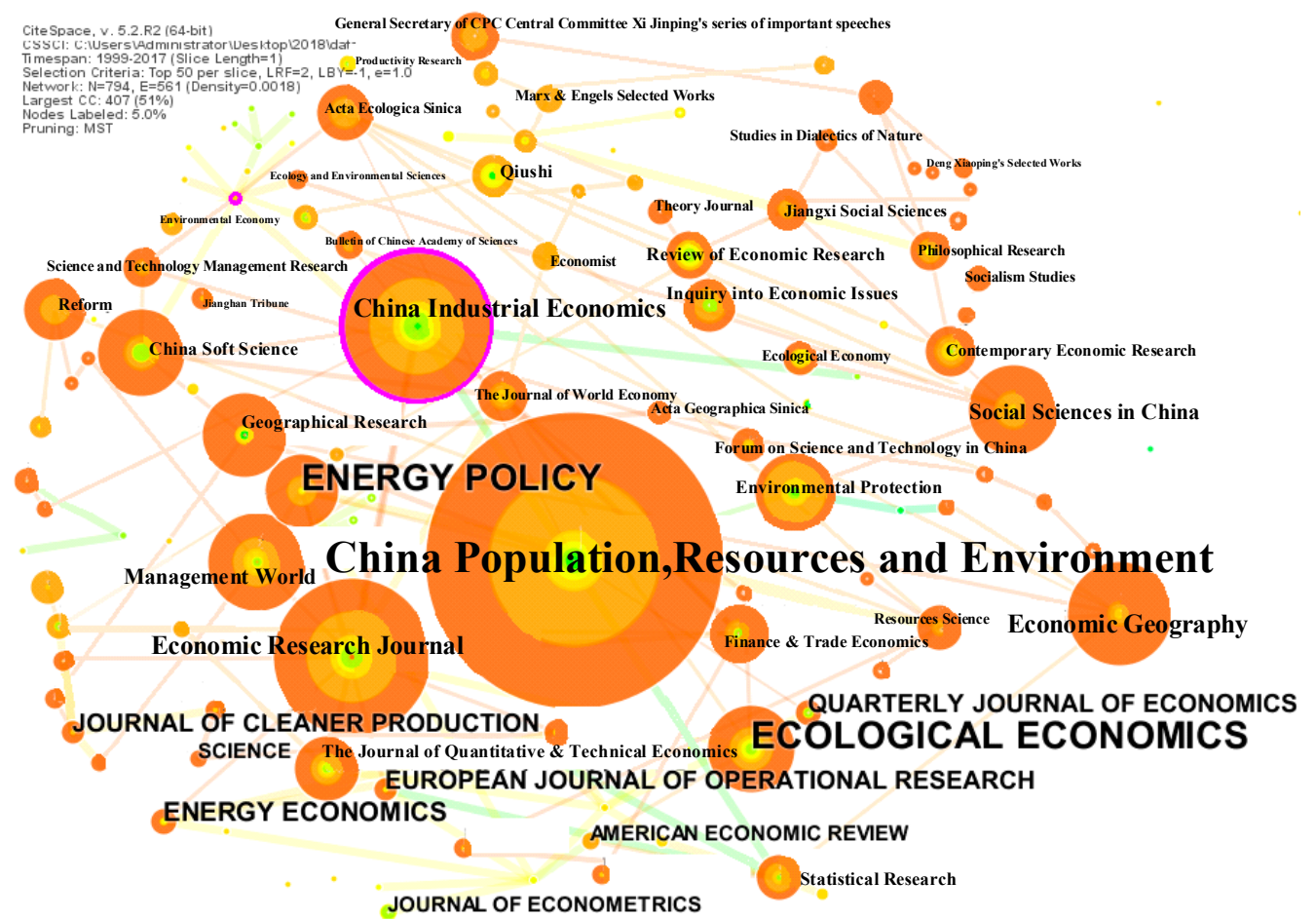

(a)

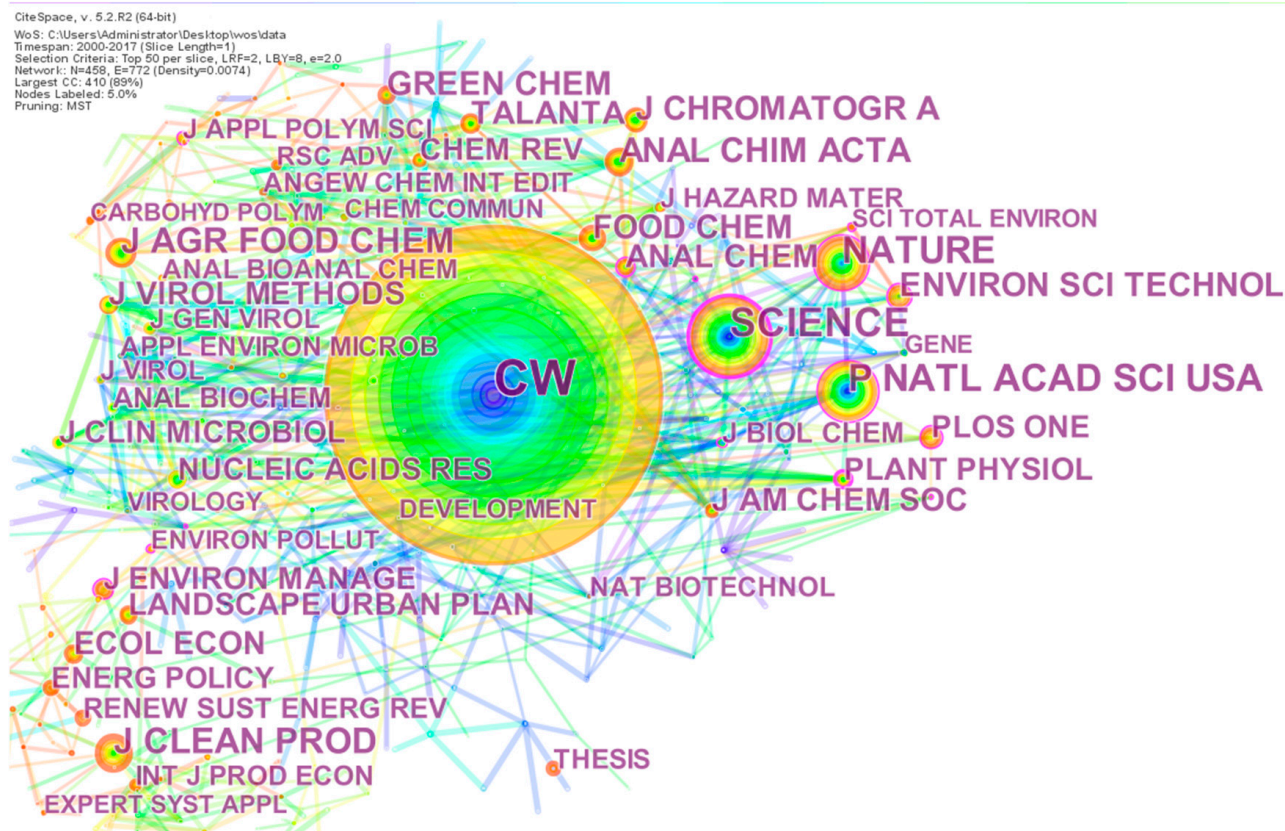

(b)

Figure 6. Co-citation network of journals. (a) Co-citation network of journals in China; (b) Co-citation network of journals in International.

In terms of the number of publications (Figure 7), China's green development research focuses on economics, management, political science, environmental science, Marxism, philosophy, law and other disciplines, especially the economics and management, which rank first and second in the number of papers published, demonstrates that green development in China is closely related to social and economic development. The papers of China's green development research are mainly published in the following journals: "Reform", "Studies on Socialism with Chinese Characteristics", "Theoretical Horizon", 
"Study and Exploration", "Inquiry Into Economic Issues", "Theory Journal", "Studies on Mao Zedong and Deng Xiaoping Theories", "Fujian Tribune (The Humanities and Social Sciences Monthly)", "China Soft Science", "Journal of South China Normal University (Social Science Edition)", "Urban Development Studies", "Hunan Social Science", "Guizhou Ethnic Studies", "Science and Technology Progress and Policy" and "Studies in Dialectics of Nature", which indicate that a great deal of research on green development has been done in the field of philosophy and Social Sciences in China, reflecting the fact that there is still room for improvement in the research of green development in China in the field of management practice.

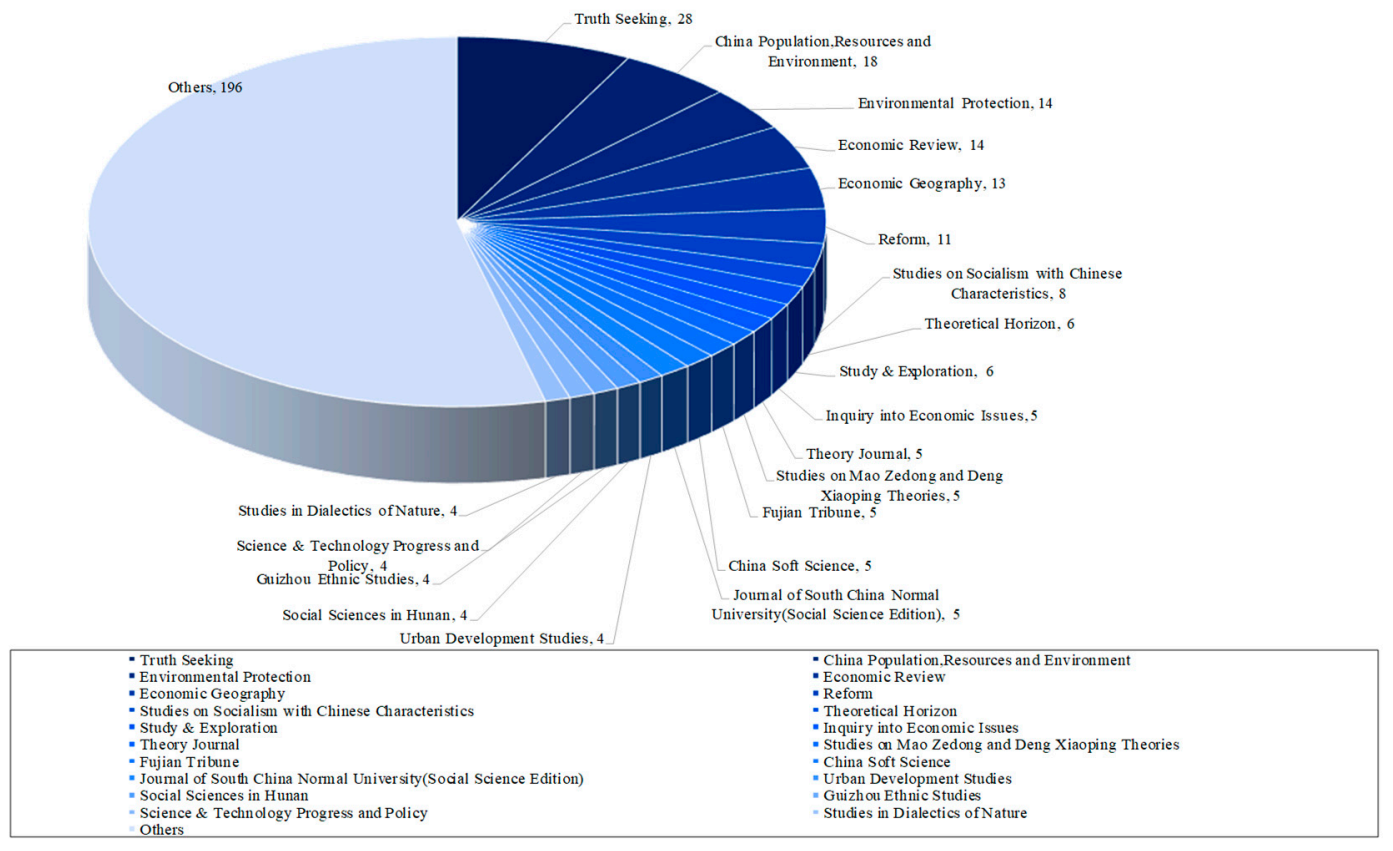

(a)

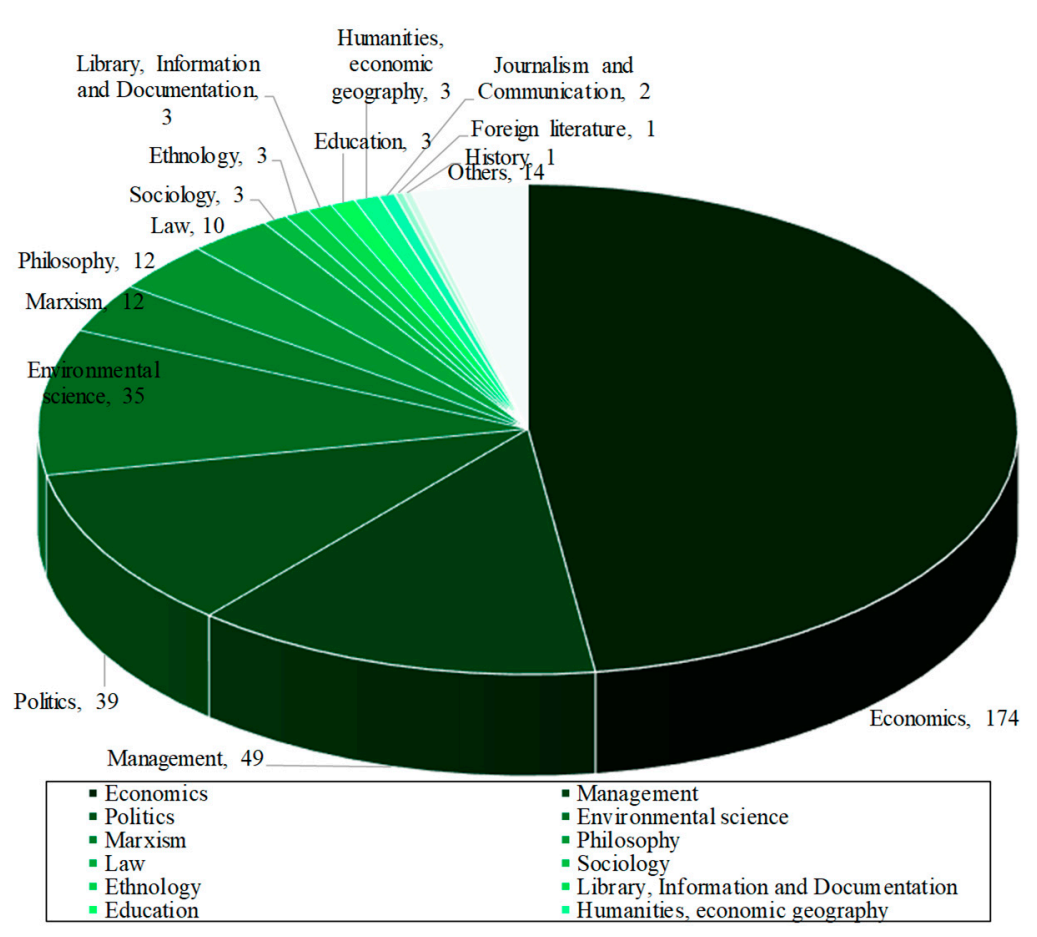

(b)

Figure 7. Cont. 


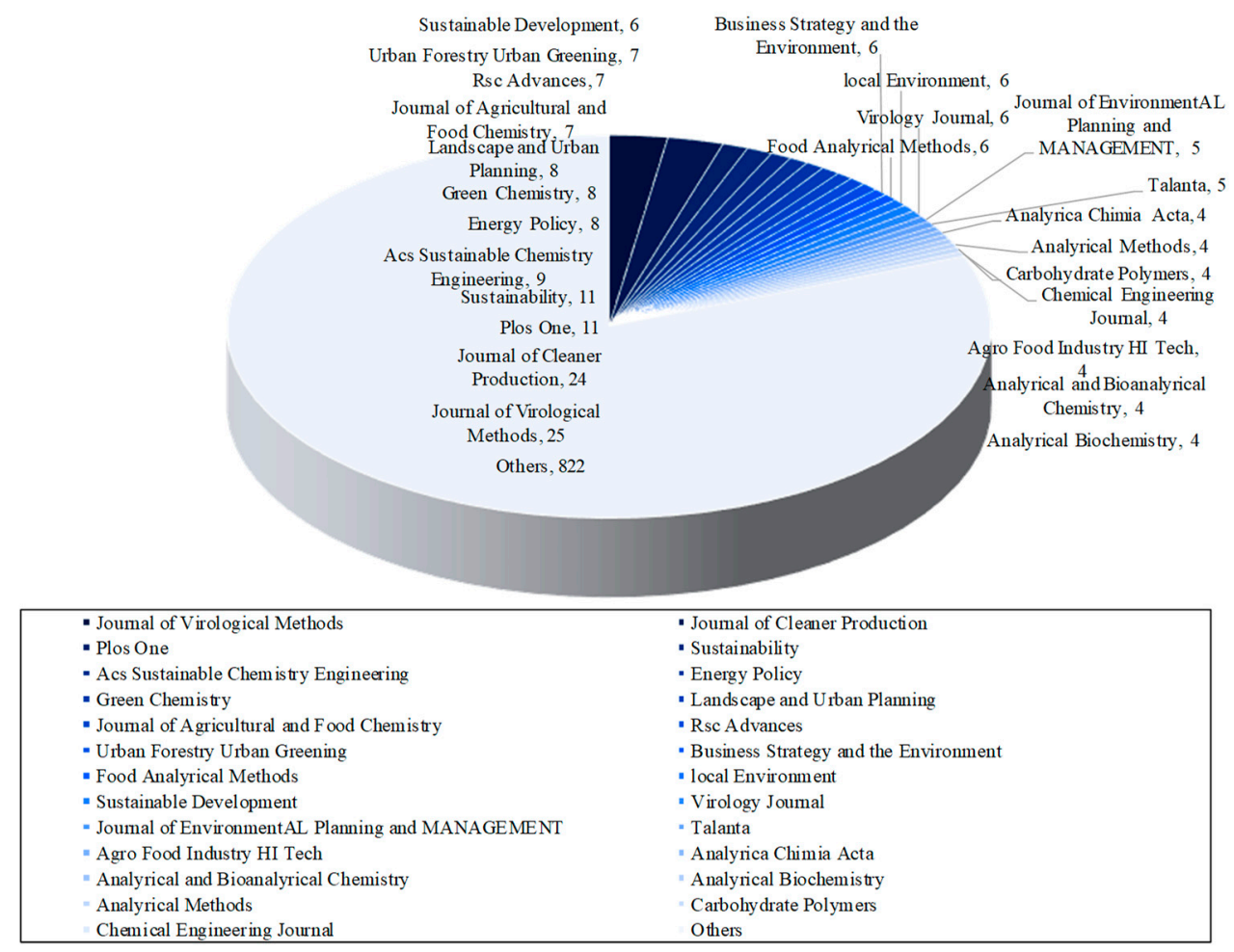

(c)

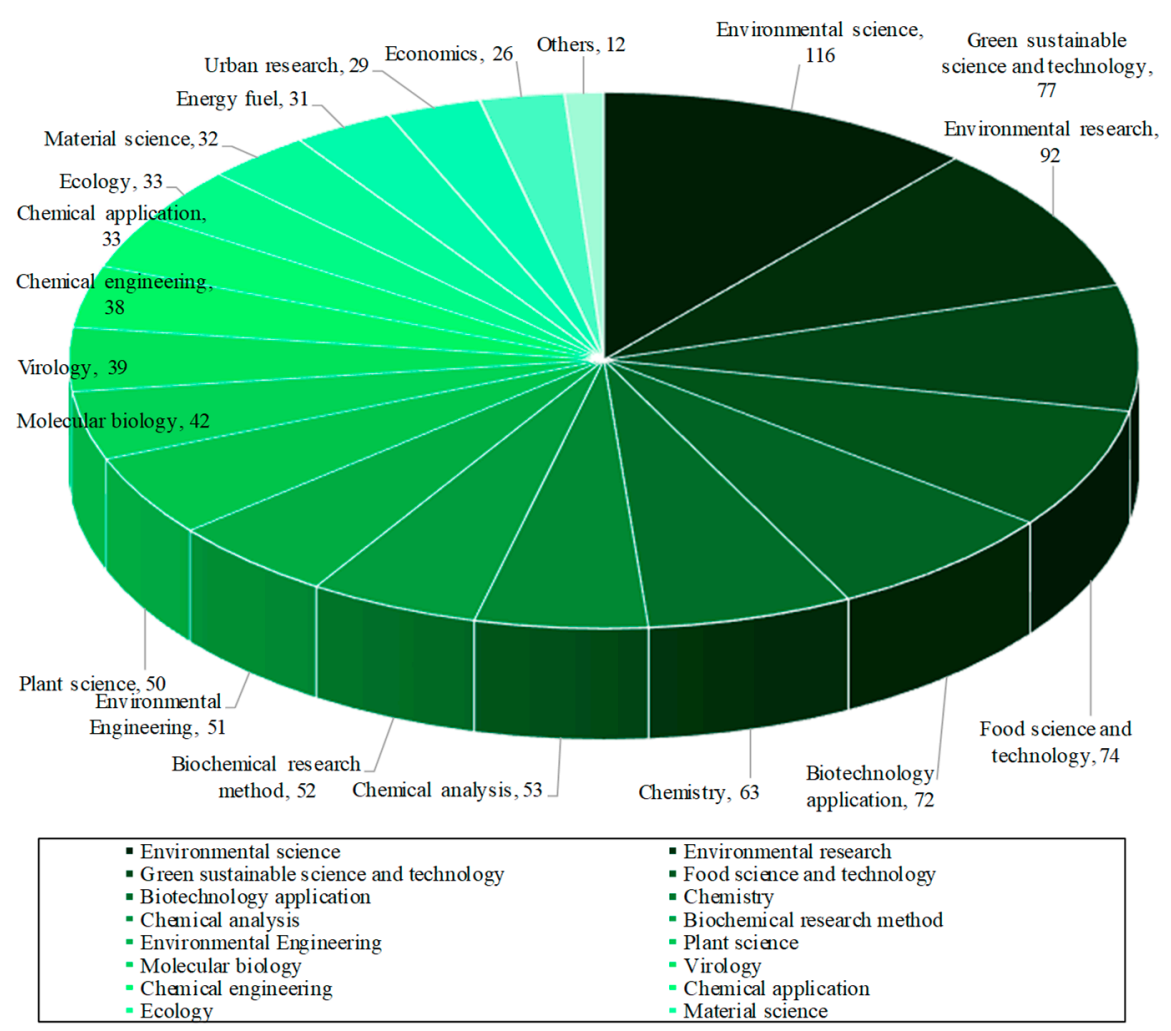

(d)

Figure 7. Journal distribution of green development research. (a) Primary journals on green development research in China; (b) distribution of major disciplines on green development research in China; (c) primary journals on green development research in International; (d) distribution of major disciplines on green development research in International. 
International green development research focuses on environmental science and engineering, environmental research, green sustainable science and technology, ecology, food science and technology, biotechnology applications, chemical and chemical analysis, chemical engineering and applications, biochemical research methods, plant science, molecular biology, virology, materials science, energy fuels, urban studies, economics and other disciplines, especially the environmental science and environmental research, green sustainable science and technology, which rank first and second in the number of papers, show that international green development is closely related to environmental and sustainable development. The papers of international green development research are mainly published in the following journals: "Journal of Virological Methods", "Journal of Cleaner Production", "Plos One", "Sustainability", "Acs Sustainable Chemistry Engineering", "Energy Policy", "Green Chemistry", "Landscape and Urban Planning", "Journal of Agricultural and Food Chemistry", "Rsc Advances", "Urban Forestry Urban Greening", "Business Strategy and the Environment", which show that in addition to the focus of environmental and sustainable development journals, the international green development research has also received special attention in the journals of virology, information science, energy, urban planning, food science, forestry and economics.

\subsection{Visual Analysis of Research Hotspots}

In order to clearly grasp the distribution of green development research hotspots, 364 Chinese and 1015 international samples were processed through the co-occurrence network analysis function of CiteSpace 5.2.R2, obtaining the distribution of green development research hotspots (Figure 8).

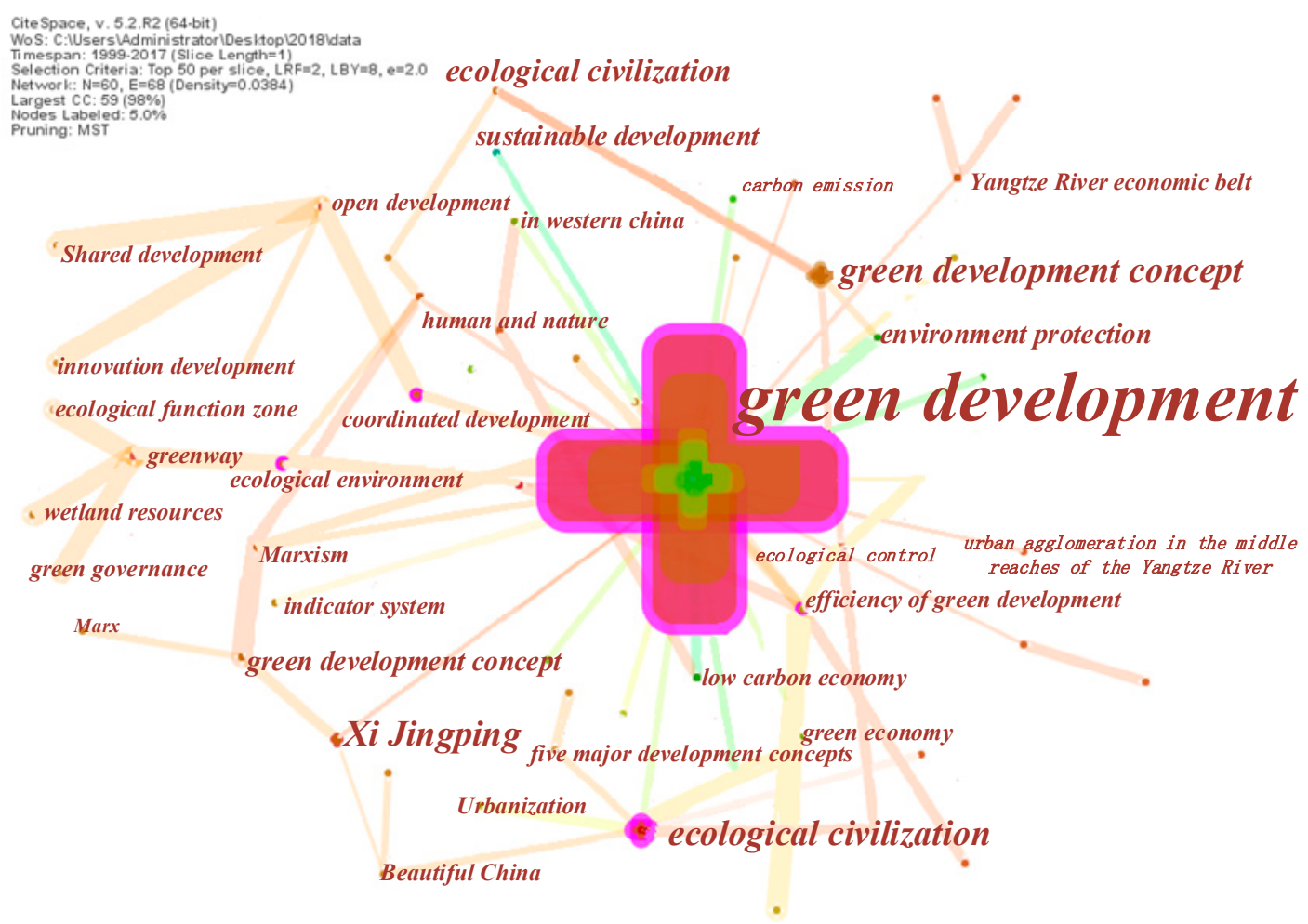

(a)

Figure 8. Cont. 


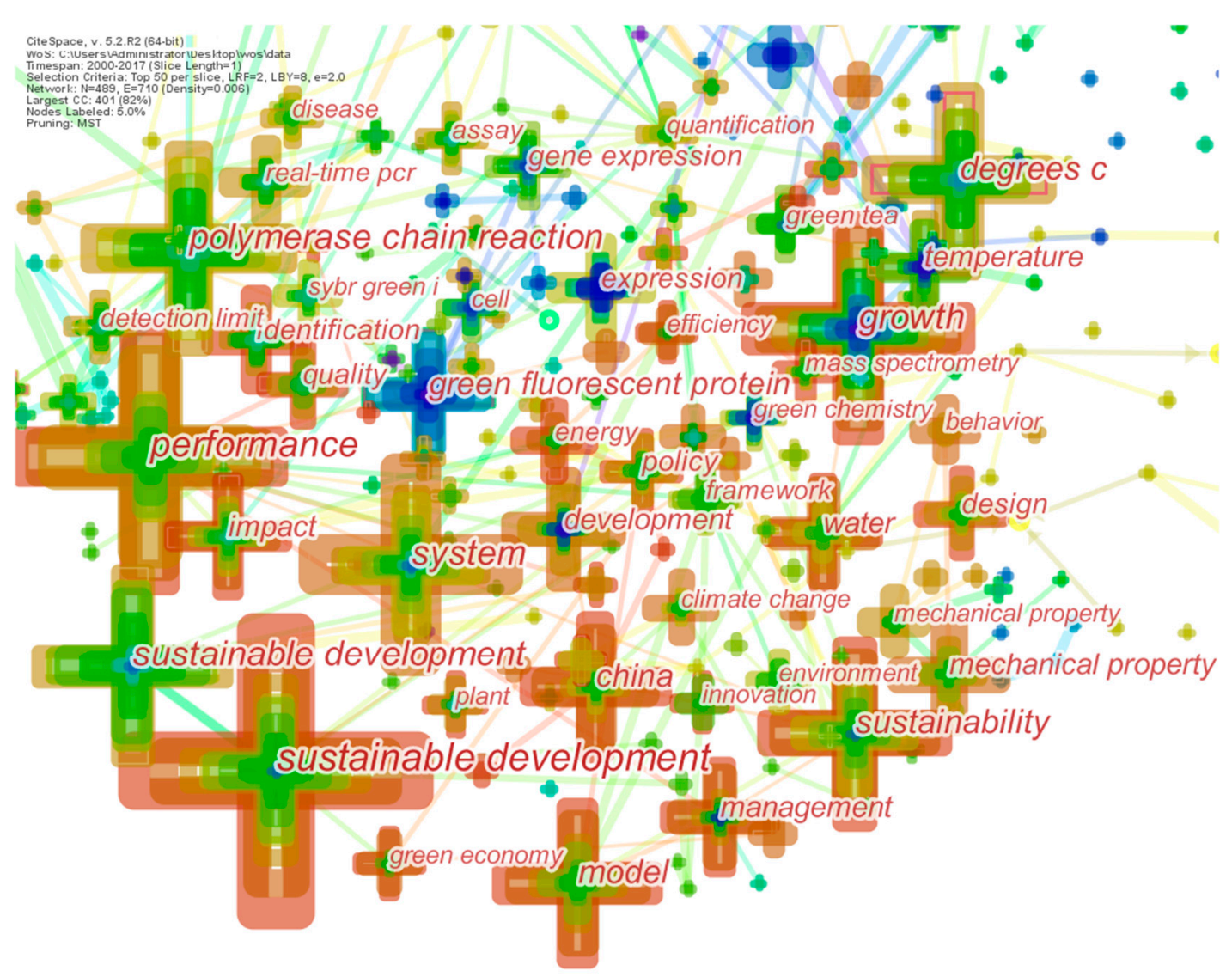

(b)

Figure 8. The co-occurrence network of terms in the 'green development research' field. (a) The co-occurrence network of terms in the 'green development research' field in China; (b) the co-occurrence network of terms in the 'green development research' field in international.

Figure 8 shows the keyword co-occurrence knowledge mapping of green development research, presenting the hotspots of Chinese and international scholars on green development research. The results show that the top 10 keywords of China's green development research are green development, ecological civilization, green development concept, ecological civilization construction, $\mathrm{Xi}$ Jinping, environmental protection, green economy and green development. Efficiency, sustainable development, ecological environment, low carbon economy, green development concept, coordinated development and people and nature according to the frequency of keyword co-occurrence, and that of international are sustainability, performance, polymerase chain reaction, growth, systems, sustainability, models, China, management and development. According to the centrality of keywords co-occurrence, the top 10 keywords are green development, ecological civilization, green development efficiency, ecological environment, coordinated development, greenway, Marxism, open development, and influence factors and environmental regulations, and that of international are real-time PCR, environmental design, assay, cell, extraction, differentiation, diagnosis, derivative, and investigation.

The data were subjected to keywords co-occurrence cluster analysis, obtaining the keywords co-occurrence clustering of China and international green development research (Figure 9), which show that the keywords co-occurrence clustering of China's green development research are green development concept, $\mathrm{Xi}$ Jinping, green development efficiency, ecological environment, ecological civilization, coordinated development, Yangtze River economic belt and industry, while for international, keywords co-occurrence clustering are green supply chain, one-step SYBR, green lizard courtship behavior, green high-efficiency liquid, plant growth, bovine viral diarrhea virus type 1, urban green space, porcine circovirus type, green tea catechins, green technology, ionic liquids, malachite green and Hong Kong. 


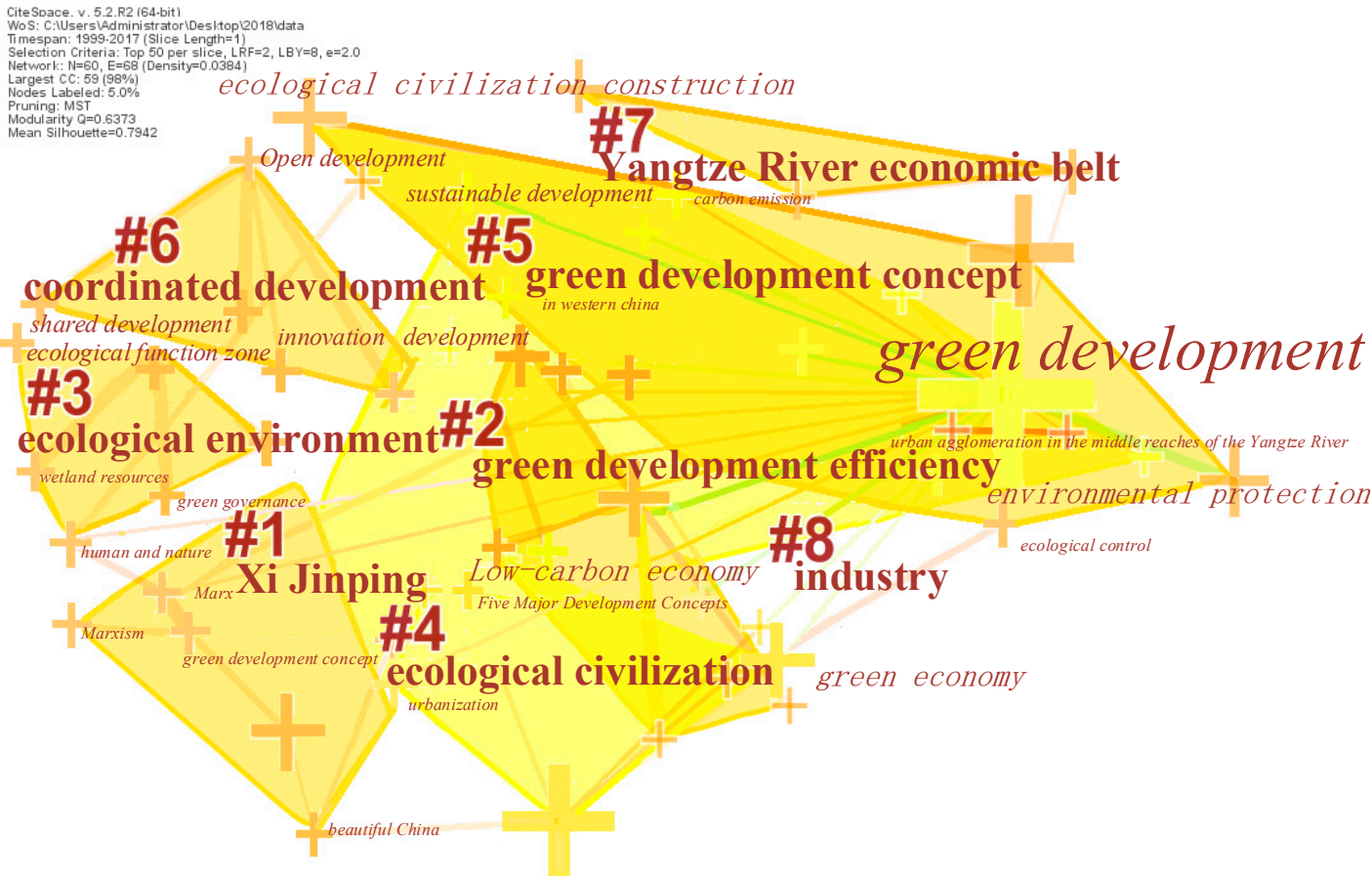

(a)

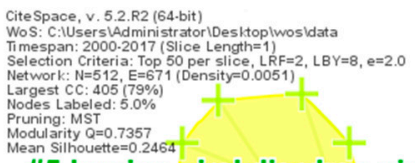

\#5 bovine viral diarrhea virus type-1 \#3 green high performance liquid

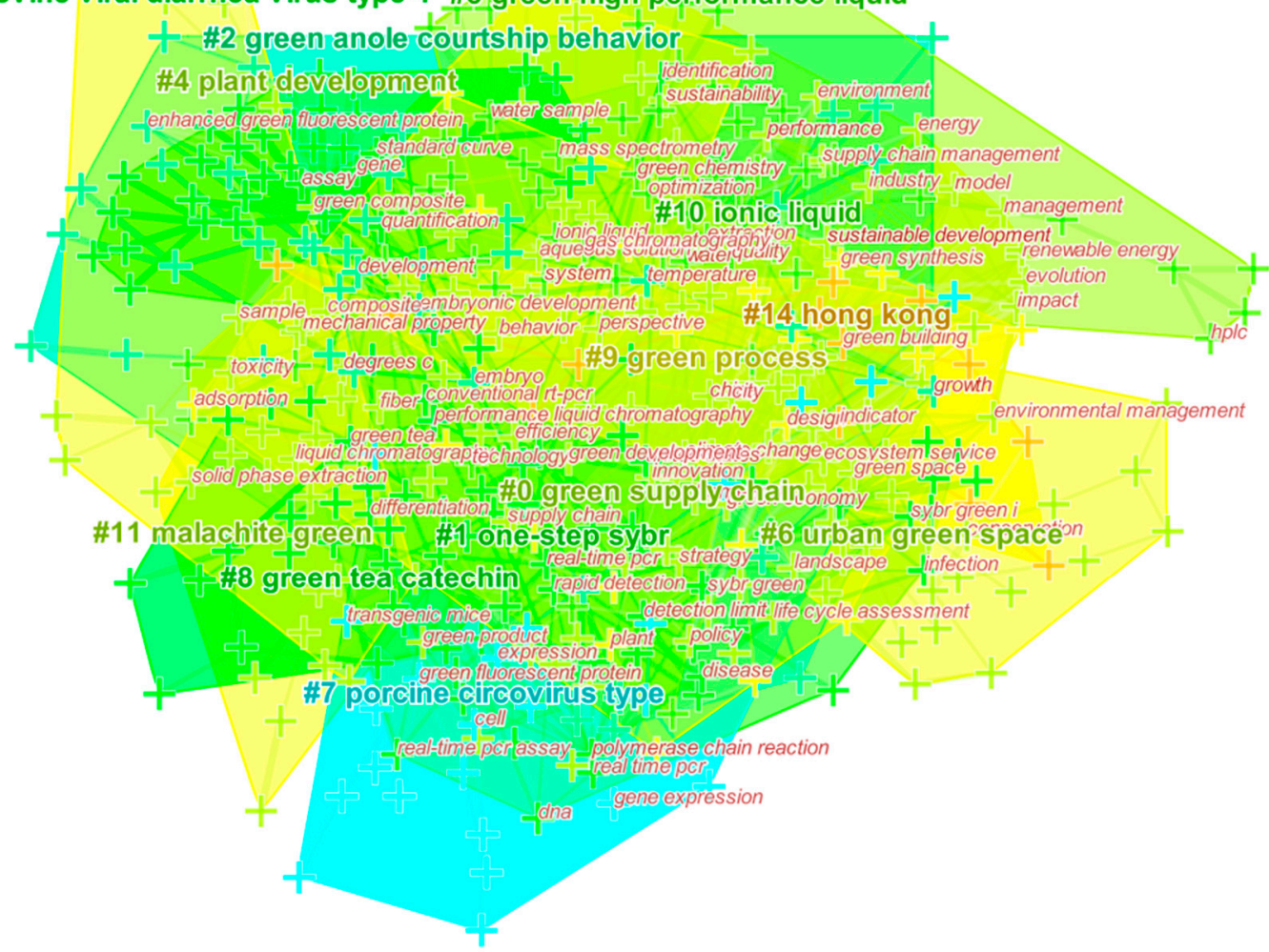

(b)

Figure 9. Keywords co-occurrence clustering knowledge map of green development research. (a) Keywords co-occurrence cluster analysis of China's green development research; (b) keywords co-occurrence cluster analysis of international green development research. 
The data were subjected to keywords co-occurrence timing analysis to obtain the evolution path of China's and international green development research hotspots (Figure 10). The results are as follows:

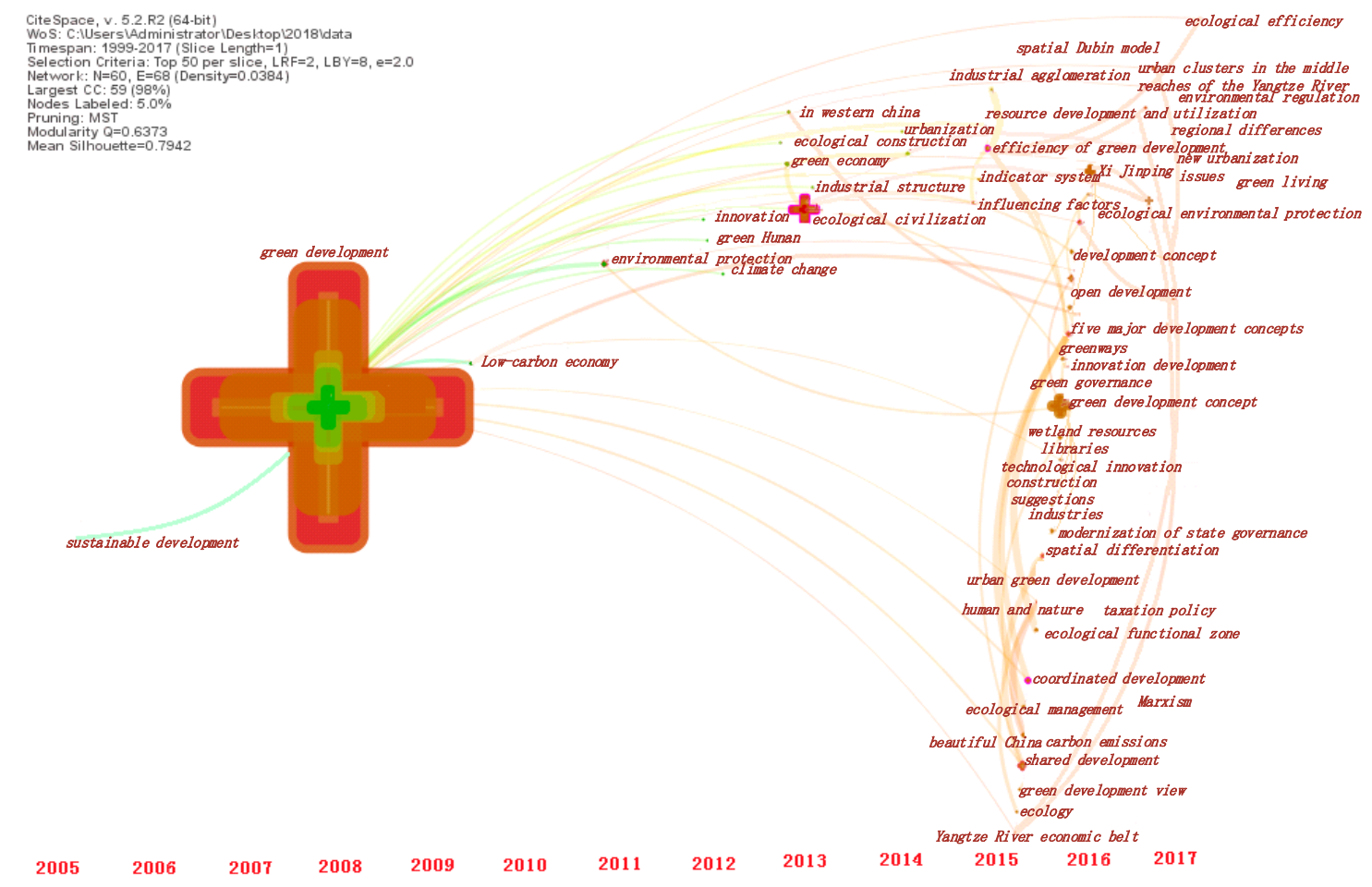

(a)

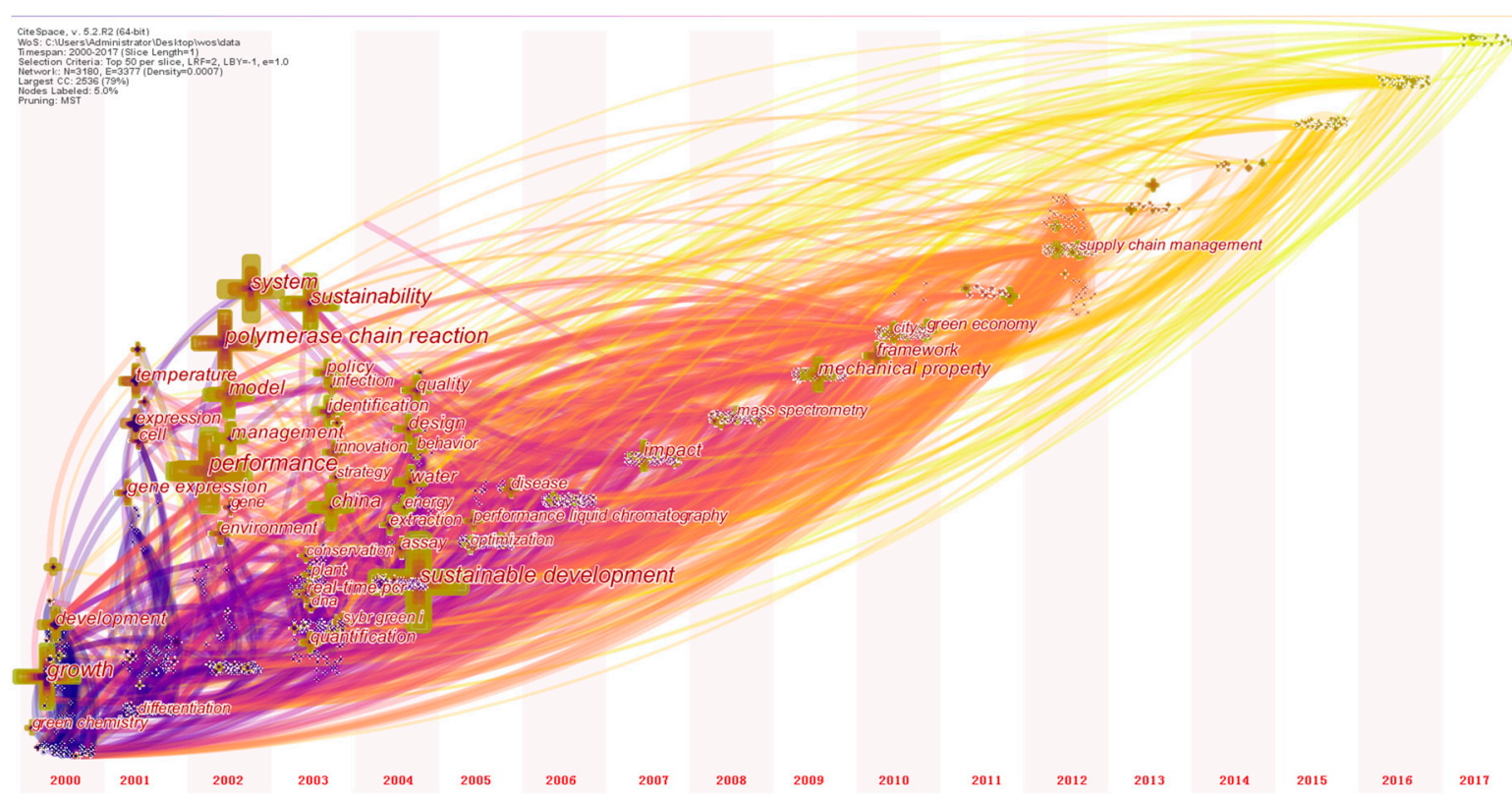

(b)

Figure 10. Keywords co-occurrence evolution of green development research. (a) Keywords co-occurrence evolution of China's green development research; (b) keywords co-occurrence evolution of international green development research.

The research hotspots of green development in China is consistent with sustainable development, which is divided into four stages. China's green development research has sprouted as early as 2005, and the first stage is from 2005 to 2007 where researchers mainly focus on sustainable development. 
The second stage is from 2008 to 2011, where the hotspots of China's green development research are relatively single, and the main hotspots are low-carbon economy and environmental protection. The third stage is from 2012 to 2015, where the hotspots of China's green development research have become richer, focusing on the field of innovation, climate change, ecological construction, ecological civilization, green economy, industrial structure, urbanization, industrial agglomeration, resource development and utilization and efficiency of green development, besides, indicator system and influencing factors have become hot research topics. Moreover, local green development research began to become a hot spot in 2012, such as the emergence of green Hunan in 2012 and the western region in 2013. The fourth stage is from 2016 to the present, where China's green development research hotspots show explosive growth, and the main research hotspots can be divided into four types. The first type of hotspots is the development concept category, which mainly includes development concept, open development, five major development concepts, green development concept, innovation development, coordinated development, shared development, and green development view; The second type of hotspots are regional and urban development category, which mainly includes regional differences, Yangtze River economic belt, spatial differentiation, urban green development, urban clusters in the middle reaches of the Yangtze River, and new urbanization; The third type of hotspots are ecological environments category, which mainly includes human and nature, ecology, ecological functional zone, ecological management, ecological environmental protection, environmental regulation, green living, beautiful China, green governance, wetland resources, greenways, and carbon emissions; The fourth type of hotspots is relatively scattered, which mainly includes ecological efficiency, spatial Dubin model, Marxism, Xi Jinping, issues, suggestions, industries, construction, technological innovation, taxation policy, modernization of state governance, and libraries.

Similarly, the international green development research hotspots are divided into four stages. The international green development research hotspots sprouted in the fields of green chemistry, climate, environment, systems, management, etc. The first stage is from 2000 to 2002, where researchers concentrated on hotspots, such as models and differences. The second stage is from 2003 to 2004, where researchers focused on sustainable development, energy, plants, water resources, research perspective focused on protection, behavior, strategy, identification, innovation and quality, and research methods focus on testing, design, quantification, real-time PCR, etc. It is worth noting that the international green development research has seen "China" in the hot keywords during this period. The third stage is from 2005 to 2009, where research hotspots are disease, mechanical properties, high performance liquid chromatography, mass spectrometry, optimization, impact. The fourth stage is from 2010 to the present, where research hotspots mainly include green economy, framework, city, supply chain management etc.

\subsection{Research Frontier and Knowledge Base Analysis}

\subsubsection{Research Frontier}

In order to clearly grasp the frontiers of green development research, we processed 364 Chinese and 1015 international data through keyword burst detection function of CiteSpace 5.2.R2. China green development research keywords detected 13 burst words (Table 7), and the international green development research keywords detected 30 burst words (Table 8).

According to the keywords burst test results of China green development research, it can be seen that during 1999 to 2015, the research frontier of green development in China started from the study of sustainable development, and then gradually extended to the fields of low-carbon economy, environmental protection, climate change, ecological civilization, green economy, urbanization, and attached great importance to innovation. In addition, the local green development research is also the frontier content of this period, the representative of the keyword is green Hunan. Since 2016, the frontier of China's green development research has focused on the spirit of the important speech of 
General Secretary Xi Jinping, focusing on the frontier keywords, such as coordinated development, ecological environment and green development concept.

Table 7. Keywords ranking list generated by burst detection in China.

\begin{tabular}{ccc}
\hline Time & Key Words & Burst \\
\hline 1999 to 2014 & sustainable development & 2.673 \\
2009 & Low-carbon economy & 1.2956 \\
2011 & Environmental protection & 1.9422 \\
2012 & Innovation & 1.2966 \\
2012 & climate change & 1.2966 \\
2013 & Green Hunan & 1.2966 \\
$2013-2015$ & Ecological Civilization & 3.0162 \\
$2013-2015$ & green economy & 2.425 \\
2014 & Urbanization & 1.9276 \\
$2016-2017$ & Coordinated development & 1.5807 \\
$2016-2017$ & Xi Jinping & 1.7783 \\
$2016-2017$ & Green development concept & 3.5921 \\
$2016-2017$ & ecosystem & 1.9018 \\
\hline
\end{tabular}

Table 8. Keywords ranking list generated by burst detection in 'International'.

\begin{tabular}{ccc}
\hline Time & Key Words & Burst \\
\hline 2000 to 2005 & Green fluorescent protein & 3.6843 \\
2011 to 2015 & disease & 4.5168 \\
2011 to 2017 & model & 7.5429 \\
2011 to 2017 & Innovation & 3.2591 \\
2011 to 2017 & which performed & 11.4625 \\
2011 to 2017 & frame & 4.5519 \\
2013 to 2017 & fiber & 3.3721 \\
2013 to 2017 & design & 5.5131 \\
2013 to 2017 & Environmental management & 3.3581 \\
2013 to 2017 & system & 8.9851 \\
2013 to 2017 & United States & 4.0529 \\
2013 to 2017 & Quantification & 4.5698 \\
2013 to 2017 & index & 3.5702 \\
2013 to 2017 & Adsorption & 3.966 \\
2013 to 2017 & Sustainability & 7.4383 \\
2013 to 2017 & sustainable development & 10.5066 \\
2013 to 2017 & Supply Chain Management & 5.1646 \\
2013 to 2017 & influences & 3.8741 \\
2013 to 2017 & landscape & 3.7682 \\
2013 to 2017 & city & 5.6167 \\
2013 to 2017 & China & 8.2369 \\
2013 to 2017 & Mechanical behavior & 6.2104 \\
\hline
\end{tabular}

According to the keyword burst detection results of the international green development research, it can be seen that the research frontier in the period of 2000 to 2005 is the green fluorescent protein in the field of cell biology, and the research frontier in the period of 2011-2015 is disease in the field of medicine. Since 2011, the frontiers include models, innovations, performance and frameworks. From 2013 to the present, the frontiers are more abundant: From the perspective of ideological, sustainability and sustainable development remain at the forefront of this period; from the perspective of the spatial region, the research countries will be dominated by China and the United States in the future; from the perspective of research methods, indicators and quantification, mechanical properties and impact are the research frontiers of this period; from the perspective of discipline, systems and management, urban and landscape design are the frontiers of this period, e.g., systems, environmental management, supply chain management, cities, landscapes, design and other frontier issues include fiber and adsorption.

\subsubsection{Knowledge Base Analysis}

In order to clearly grasp the knowledge base of green development research, we processed 364 Chinese and 1015 international data through co-citation analysis function of CiteSpace 5.2.R2, and selected co-cited documents as network nodes to sequentially access the analysis of Chinese and 
international data, obtaining the distribution of co-cited literature in the Green Development Study (Tables 9 and 10).

Table 9. Highly Cited Literature of green development research.

\begin{tabular}{|c|c|c|c|}
\hline Frequency & Author & Year & Title \\
\hline 10 & Xiaoxi Li & 2014 & Estimation of the human green development index \\
\hline 10 & Bing Wang & 2010 & $\begin{array}{l}\text { China's regional environmental efficiency and environmental total factor } \\
\text { productivity growth }\end{array}$ \\
\hline 9 & Angang Hu & 2014 & $\begin{array}{l}\text { Green Development: Functional Definition, Mechanism Analysis and } \\
\text { Development Strategy }\end{array}$ \\
\hline 8 & $\begin{array}{l}\text { World Commission on } \\
\text { Environment and } \\
\text { Development }\end{array}$ & 1987 & $\begin{array}{l}\text { Report of the world commission on environment and development: our } \\
\text { common future (the Brundtland Report) }\end{array}$ \\
\hline 8 & $\begin{array}{l}\text { Propaganda Department } \\
\text { of the CPC Central } \\
\text { Committee }\end{array}$ & 2016 & General Secretary Xi Jinping's series of important speeches \\
\hline 7 & Marx & 1844 & 1844 Economics and Philosophy Manuscript \\
\hline 7 & Jianjun Zhao & 2012 & $\begin{array}{l}\text { Reconciliation between man and nature: a review of the values of "green } \\
\text { development" }\end{array}$ \\
\hline 7 & Albino V & 2009 & $\begin{array}{l}\text { Environmental strategies and green product development: an overview on } \\
\text { sustainability-driven companies }\end{array}$ \\
\hline 7 & Jianhuan Huang & 2014 & $\begin{array}{l}\text { The Mechanism of Financial Development Affecting Regional Green } \\
\text { Development-Based on Ecological Efficiency and Spatial Measurement }\end{array}$ \\
\hline 6 & Nanping Jiang & 2013 & Some problems in the green development of China's economy \\
\hline 6 & Xiaoxi Li & 2011 & $\begin{array}{l}\text { Compilation of China's Green Development Index-A Brief Account of the } \\
2010 \text { China Green Development Index Annual Report-Inter-provincial } \\
\text { Comparison }\end{array}$ \\
\hline 5 & Sarkis J & 2011 & $\begin{array}{l}\text { An organizational theoretic review of green supply chain management } \\
\text { literature }\end{array}$ \\
\hline 5 & Welch CJ & 2009 & $\begin{array}{l}\text { Performance to burn? Re-evaluating the choice of acetonitrile as the } \\
\text { platform solvent for analytical HPLC }\end{array}$ \\
\hline 5 & Chen SY & 2014 & 'Green' productivity growth in China's industrial economy \\
\hline 4 & Bai CG & 2010 & Green supplier development: analytical evaluation using rough set theory \\
\hline
\end{tabular}

Table 10. High central literature of green development research.

\begin{tabular}{|c|c|c|c|}
\hline Center Degree & Author & Year & Title \\
\hline 0.05 & Jianhuan Huang & 2014 & $\begin{array}{l}\text { The Mechanism of Financial Development Affecting Regional Green } \\
\text { Development-Based on Ecological Efficiency and Spatial Measurement }\end{array}$ \\
\hline 0.05 & Nanping Jiang & 2013 & Some problems in the green development of China's economy \\
\hline 0.04 & Angang $\mathrm{Hu}$ & 2014 & $\begin{array}{l}\text { Green Development: Functional Definition, Mechanism Analysis and } \\
\text { Development Strategy }\end{array}$ \\
\hline 0.04 & Lesage J & 2009 & Introduction to Spatial Econometrics \\
\hline 0.04 & Angang $\mathrm{Hu}$ & 2014 & China: Innovative Green Development \\
\hline 0.01 & Constable DJC & 2007 & $\begin{array}{l}\text { Key Green Chemistry Research Areas-A Perspective from Pharmaceutical } \\
\text { Manufacturers }\end{array}$ \\
\hline
\end{tabular}

As early as the mid-19th century, Marx wrote the "Manuscript of Economics and Philosophy in $1844^{\prime \prime}$, which first explained the origin of economy and economics from the perspective of production labor practice [30]. The green economy, which is one of the hotspots and frontiers of green development research, has also received theoretical support in this work. In the context of the deteriorating human living environment and the increasing emphasis on environmental protection in the world, the World Commission on Environment and Development (WCED) issued "Our Common Future" in 1987, formally proposed the concept of sustainable development [31], which has been widely recognized by people from all walks of life in the world. In 2016, General Secretary Xi Jinping's Series of Important Speeches, the book uses a single chapter on the theory of two mountains (Lucid waters and lush mountains are invaluable assets) to elaborate on vigorously promoting the construction of ecological civilization, pointing out that only by paying more attention to the productive factor of ecological 
environment, respecting the law of natural ecological development and protecting and utilizing the ecological environment can we develop the productive forces better and it is necessary to promote the green development more consciously [32].

According to the results of the previous analysis, it has been found that modeling research methods are becoming the frontier and hotspot of green development research. Lesage et al. studied spatial econometric models and methods, and discussed spatial autoregressive processes, extending the traditional regression model [33].

Green Chemistry: From the perspective of pharmaceutical companies, Dunn et al. pointed out that green chemistry is an important research direction for future chemistry [34]. Acetonitrile is currently the preferred organic solvent for reversed-phase high performance liquid chromatography, but it also has the disadvantage of over-performance. Welch et al. studied whether the green solvent, such as ethanol, can replace acetonitrile in some cases [35]. Wang found that excessive use of energy, sulfur dioxide $\left(\mathrm{SO}_{2}\right)$ and emissions of chemical oxygen demand (COD) are the main sources of environmental inefficiency. It is also found that the eastern region of China is more environmentally efficient than the Midwest [36].

Green supply chain management: Bai et al. believe that the development of green suppliers is necessary for the effective management of green supply chains [37]. Sharkis et al. pointed out that in the future, green supply chain management research can be deeply studied on the basis of innovation diffusion theory, path dependence theory, social embedded theory, structural theory and other theories [38].

Green products and green finance: Albino et al. found that in the face of various challenges brought about by environmental sustainability, companies can play an important role through green technology and green product development strategies and practices [39]. Huang et al. believed that finance should play an important role in promoting green development. In the study, they analyzed the impact mechanism of financial development on regional green development, and used ecological efficiency to reflect the level of regional green development [40].

Calculation of green development indicators: From the aspects of background, ideas, structure and forecasting, Li et al. analyzed the annual report on China's Green Development Index 2010- inter provincial comparison, which was compiled by China Economic Monitoring and Analysis Center of the National Bureau of Statistics in conjunction with universities and colleges [41]. Li et al. constructed the concept and calculation method of the human green development index, and then calculated the green development index of 123 countries on the basis of 12 elements indicators [42]. Chen et al. studied the change pattern of "green" total factor productivity growth of 38 industrial sectors in China between 1980 and 2010, and found that Chinese industry has not yet embarked on a path of sustainable and low carbon growth [43].

Exploration of green development theory: Starting from Marx's theory of "reconciliation between man and nature", Zhao examined green development from the perspective of value revolution. The study concluded that green development is a development of economy, introversion and identity [44]. Jiang et al. believed that the connotation and essence of green development should be defined on the basis of the concept of "rational utilization of resources and energy, moderate development of economy and society, the balance of damages and compensation, and harmonious coexistence between man and nature" [45]. Hu et al. believe that the concept of green development is the second generation of sustainable development concept, with more emphasis on system, integrity and coordination of economic, social and natural system, which is a development strategy that China must choose [46]; The study also pointed out that mankind is in the era of the green industrial revolution, an era striding towards green civilization, and green development is a combination of the system of society, economy and nature. The theoretical basis of green development is the unity of nature and humanity in traditional Chinese philosophy, natural dialectics and modern sustainable development theory in Marxist philosophy [47]. 
In summary, the green economy, which is one of the hotspots and frontiers of green development research, has received theoretical support in work which is called "Manuscript of Economics and Philosophy in 1844" by Marx. The concept of green development is the inheritance and development of the concept of sustainable development proposed by the World Commission on Environment and Development in 1987. Moreover, the theory of two mountains proposed by General Secretary $\mathrm{Xi}$ Jinping in 2016 is one of the important theoretical supports for promoting green development. In addition, the knowledge base of green development research includes spatial measurement models and methods, green chemistry, green supply chain management, green products and green finance, green development indicators, and exploration of green development theory.

\section{Discussion}

The Chinese longing for the beauty of natural environment since ancient times is consistent with today's yearning for beautiful China in ideology, which is the same with green development and sustainable development. Green development and sustainable development, not only the inheritance of sustainable development, but also the theoretical innovation of sustainable development in China, are a major theoretical contribution of socialism with Chinese characteristics to cope with the objective reality of global ecological environment deterioration, which conforms to the historical trend of evolution. Marxism tells us to integrate theory with practice, and practice is the sole criterion for testing truth. Since green development is to adhere to the people-centered concept of development, then green development should ultimately be implemented as the green development of people's participation, which is inseparable from green behavior. According to the green behavior generation mechanism: Green development needs $\rightarrow$ green development demands $\rightarrow$ green development motivations $\rightarrow$ green behaviors, it can be seen that. First of all, it is needed for human to have green development needs and a desire for a high-quality ecological environment. When there is a need for green development, there is a green development demand. Immediately afterwards, it creates a green development motivation, and finally implemented it into green behavior through practice, realizing the green development of people's participation.

At present, China remains in the key time of the first step in the two centenary goals, facing the test of building a well-off society in 2020, where green development, a must for China, is of great importance. On the basis of comprehensively summarizing the historical evolution, China should make full use of the advanced experience adopted by the United States, India, Japan, the United Kingdom, Australia and other countries in dealing with the contradictions and conflicts between the ecological environment and social and economic development issues, learning from the failure cases, taking the people as the center and properly handle the relationship between green development and development for innovation, coordination, opening and sharing, and applying the green low carbon cycle idea to all walks of life.

\section{Conclusions}

This paper draws the characteristics of green development theory by digging in depth the information of research papers on green development. First, the quantitative trends of published papers can more intuitively reflect whether the research topic continues to be concerned by researchers. By comparing the number of published papers on green development research by researchers in China and other countries, we found that: This theme continues to receive the attention from people, and it is valuable to study in the future. Second, the geographical distribution of the research topic can more intuitively reflect how the areas of concern for the topic are distributed. Through the study of spatial and temporal distribution characteristics of green development research, this paper reveals the regional distribution characteristics of the research. Third, this paper obtains the main supporting disciplines and institutions of green development research by researching the distribution characteristics of journals and institutions. In addition, this research can provide new researchers with information about green development to find important references and applications. First, using CiteSpace software to 
conduct in-depth research on green development, new ideas about the study of green development are provided. Second, the research hotspot analysis can reveal the main focus areas of green development, making the theoretical focus on green development research clearer. Third, frontier analysis can provide researchers with up-to-date information on green development research and provide valuable information or references for their potential research areas. Fourth, through the knowledge base research on green development, this paper reveals the widely accepted classical theory and knowledge information on this field.

This paper emphatically analyze China's and international green development research from four aspects: Temporal and spatial distribution characteristics, research hotspots, research frontiers and research knowledge base based on the bibliometric method, mapping knowledge domains and spatial analysis method, using CiteSpace 5.2.R2, Arc GIS and Excel software to carry out visualization analysis of co-operation network, co-occurrence network and co-citation on 364 Chinese documents with their citations published in the CSSCI database (1999-2017) and 1015 English documents with their citations recorded in the SSCI and SCI databases (2000-2017). The research findings are as follows:

\subsection{Time and Space Distribution}

The research literature on green development of China's and international scholars shows a trend of increasing year by year, and the gap between Chinese and international scholars in the number of published documents on green development shows an M-shaped evolution trend. In the future, the number of Chinese scholars' research papers on green development will exceed that of international scholars year by year.

The United States and China are both major countries in green development research, and both of them are closely cooperating with most countries or scientific research institutions in the cooperation network; however, there is still room for Chinese scholars to have improvement in the number of the research on green development in the international academic community. From the north-south perspective, the results of green development research are mainly concentrated in the northern hemisphere countries, while the southern hemisphere countries are less distributed. From the east-west perspective, the results of green development research are widely distributed in the eastern and western hemispheres. In the western hemisphere countries and regions, the results of green development research are mainly concentrated in the United States, while in the eastern hemisphere countries and regions, the results of green development research are mainly concentrated in China, India, Japan, the United Kingdom, Australia and Germany.

China's research institutions on green development research mainly come from party and government departments, magazines, research institutes, ordinary higher education institutions, and party schools. The main party and government departments include the Ministry of Housing and Urban-Rural Development, the Jiangxi Provincial Committee of the Communist Party of China, the main magazines include the Environmental Protection Magazine, etc. The main research institutes include the Institute of Urban Development and Environment of the Chinese Academy of Social Sciences and the Institute of Rural Development of the Chinese Academy of Social Sciences. Institute of Geographical Sciences and Natural Resources Research, Chinese Academy of Sciences, China Social Science Evaluation Center, Chinese Academy of Social Sciences, Institute of Science, Technology and Management, Chinese Academy of Sciences; major institutions of higher learning include School of Public Administration, South China Normal University, Department of Social Sciences, Central South University of Forestry and Technology, China Geology University Marxism College, Wuhan University Marxism College, Hefei University of Technology, Fudan University Marxism College, Central South University of Forestry and Technology Marxism College, Dalian University of Technology Management and Economics Department, Henan University of Technology; major party schools, including the CPC Henan Provincial Party School, etc. The international research institutions on green development research mainly come from research institutes and ordinary higher education institutions. The main research institutes include the Chinese Academy of Sciences and the 
Chinese Academy of Agricultural Sciences; the main institutions of higher learning include the Islamic Azad University of Iran, the University of Tokyo, the University of Queensland, the State University of Michigan, the State University of Washington, the State University of Washington, the Baylor College of Medicine, and the Sao Paulo, Brazil. State University, Malaysia University, Indian Institute of Technology, South China Agricultural University, Hong Kong Polytechnic University, National University of Singapore, University of Birmingham, University of Sheffield, UK, Lund University, Sweden. Chinese scientific research institutions represented by the Chinese Academy of Sciences, the Chinese Academy of Agricultural Sciences, South China Agricultural University, and the Hong Kong Polytechnic University have actively participated in international academic cooperation in green development research.

China's scientific research team on green development research is mainly centered on Hu, Huang, Zhang, Qin, Li, Zhao, Feng, Liu S, Fan etc. The international research team on green development research mainly centered on Wang, Shen, Zhang, Liu, Hilker, Jiao, Sadiku, Kim, Hammer, Tayade, Zhang, Zhao, Arakawa and Pradhan etc.

The most frequently cited journals in China are the environmental, geographical, economic and management journals, among which the three most central Chinese journals are "China industrial economics", "China Soft Science" and "Acta Ecologica Sinica". However, the most central journal is not a Chinese journal, but "International Economics and Economic Policy". For international, the most frequently cited are the journals of SSCI and SCI, such as environment, food science and chemistry.

China's green development is closely related to social and economic development, and a large number of theoretical explorations have been carried out in the field of philosophy and social sciences, however, there is still room for improvement in the field of management practice. International green development is closely related to the environment and sustainable development. In addition to being widely concerned by environmental and sustainable development journals, it is also focused on virology, information science, energy, urban planning, food science, forestry and economics.

\subsection{Research Hotspots Distribution}

The research hotspots of green development in China is consistent with sustainable development, which is divided into 4 stages. China's green development research has sprouted as early as 2005, and the first stage is from 2005 to 2007 where researchers mainly focus on sustainable development. The second stage is from 2008 to 2011, where the hotspots of China's green development research are relatively single, and the main hotspots are low-carbon economy and environmental protection. The third stage is from 2012 to 2015, where the hotspots of China's green development research have become richer, focusing on the field of innovation, climate change, ecological construction, ecological civilization, green economy, industrial structure, urbanization, industrial agglomeration, resource development and utilization and efficiency of green development, besides, indicator system and influencing factors have become hot research topics. Moreover, local green development research began to become a hot spot in 2012. The fourth stage is from 2016 to the present, where China's green development research hotspots show explosive growth, and the main research hotspots can be divided into four types. The first type of hotspots is the development concept category, which mainly includes development concept, open development, five major development concepts, green development concept, innovation development, coordinated development, shared development, and green development view; The second type of hotspots are regional and urban development category, which mainly includes regional differences, Yangtze River economic belt, spatial differentiation, urban green development, urban clusters in the middle reaches of the Yangtze River, and new urbanization; The third type of hotspots are ecological environments category, which mainly includes human and nature, ecology, ecological functional zone, ecological management, ecological environmental protection, environmental regulation, green living, beautiful China, green governance, wetland resources, greenways, and carbon emissions; The fourth type of hotspots is relatively scattered, which mainly includes ecological efficiency, spatial Durbin model, Marxism, Xi Jinping, issues, suggestions, 
industries, construction, technological innovation, taxation policy, modernization of state governance, and libraries.

Similarly, the international green development research hotspots are divided into four stages. The international green development research hotspots sprouted in the fields of green chemistry, climate, environment, systems, management, etc. The first stage is from 2000 to 2002, where researchers concentrated on hotspots, such as models and differences. The second stage is from 2003 to 2004, where researchers focused on sustainable development, energy, plants, water resources, research perspective focused on protection, behavior, strategy, identification, innovation and quality, and research methods focus on testing, design, quantification, real-time PCR, etc. It is worth noting that the international green development research has seen "China" in the hot keywords during this period. The third stage is from 2005 to 2009, where research hotspots are disease, mechanical properties, high performance liquid chromatography, mass spectrometry, optimization, impact. The fourth stage is from 2010 to the present, where research hotspots mainly include green economy, framework, city, supply chain management etc.

\subsection{Research Frontier Distribution}

During 1999 to 2015, the research frontier of green development in China started from the study of sustainable development, and then gradually extended to the fields of low-carbon economy, environmental protection, climate change, ecological civilization, green economy, urbanization, and attached great importance to innovation. In addition, the local green development research is also the frontier content of this period, the representative of the keyword is green Hunan. Since 2016, the frontier of China's green development research has focused on the spirit of the important speech of General Secretary Xi Jinping, focusing on the frontier keywords, such as coordinated development, ecological environment and green development concept.

During 2000 to 2005, the research frontier of green development in international is the green fluorescent protein in the field of cell biology, and the research frontier in the period of 2011-2015 is disease in the field of medicine. Since 2011, the frontiers include models, innovations, performance and frameworks. From 2013 to the present, the frontiers are more abundant: From the perspective of ideological, sustainability and sustainable development remain at the forefront of this period; From the perspective of the spatial region, the research countries will be dominated by China and the United States in the future; From the perspective of research methods, indicators and quantification, mechanical properties and impact are the research frontiers of this period; From the perspective of discipline, systems and management, urban and landscape design are the frontiers of this period, e.g., systems, environmental management, supply chain management, cities, landscapes, design and other frontier issues include fiber and adsorption.

\subsection{Knowledge Base of Research}

The green economy, which is one of the hotspots and frontiers of green development research, has received theoretical support in work which is called "Manuscript of Economics and Philosophy in 1844 " by Marx. The concept of green development is the inheritance and development of the concept of sustainable development proposed by the World Commission on Environment and Development in 1987. Moreover, the theory of two mountains proposed by General Secretary Xi Jinping in 2016 is one of the important theoretical supports for promoting green development.

In addition, the knowledge base of green development research includes spatial measurement models and methods, green chemistry, green supply chain management, green products and green finance, green development indicators, and exploration of green development theory.

The limitation of this paper lies in comparing China and other countries as two whole, while two or more countries can be more specific in future study. Researchers are advised to keep up with the frontiers and hotspots of green development in future research, draw research paradigms and methods from different disciplines, and strengthen academic exchanges between institutions and countries. 
Author Contributions: All authors contributed equally to this work. All authors wrote, reviewed, and commented on the manuscript. All authors have read and approved the final manuscript.

Funding: Special Funds of the National Social Science Fund of China (18VSJ038).

Acknowledgments: The authors would like to acknowledge the professionals who collaborated on this study. We would also like to thank all the reviewers who provided suggestions to improve this paper.

Conflicts of Interest: The authors declare no conflict of interest. The funders had no role in the design of the study; in the collection, analyses, or interpretation of data; in the writing of the manuscript, or in the decision to publish the results.

\section{References}

1. Feng, C.; Wang, M.; Liu, G.C.; Huang, J.B. Green development performance and its influencing factors: A global perspective. J. Clean. Prod. 2017, 144, 323-333. [CrossRef]

2. Yuan, B.; Xiang, Q. Environmental regulation, industrial innovation and green development of Chinese manufacturing: Based on an extended CDM model. J. Clean. Prod. 2018, 176, 895-908. [CrossRef]

3. Liu, D. The Scientific Connotation and Value Orientation of Green Development Concept. Jiangsu Soc. Sci. 2017, 3, 1-7. (In Chinese) [CrossRef]

4. Ye, H. History of Psychology; East China Normal University Press: Shanghai, China, 2009; p. 218. (In Chinese)

5. Gao, X. Intuition Psychology; People's Education Press: Beijing, China, 2011; pp. 56-90. (In Chinese)

6. Wang, J.; Cao, D.; Chen, X. Preliminary Conception of National Green Development Strategy Planning. Environ. Prot. 2006, 6, 39-43, 49. (In Chinese) [CrossRef]

7. Yang, D.; Gao, F. Theory Analysis of Green Development Road. Sci. Manag. Res. 2006, 20-23. (In Chinese) [CrossRef]

8. Xinhua News Agency. Suggestions of the Central Committee of the Communist Party of China on Formulating the 13th Five-Year Plan for National Economic and Social Development. 2015. Available online: http:/ / www.gov.cn/xinwen/2015-11/03/content_5004093.htm (accessed on 21 November 2018).

9. Xi, J. A New Starting Point for China's Development a New Blueprint for Global Growth. 2016. Available online: http:/ / www.china.org.cn/chinese/2016-09/05/content_39233599.htm (accessed on 21 November 2018).

10. Xinhua News Agency. Secure a Decisive Victory in Building a Moderately Prosperous Society in All Respects and Strive for the Great Success of Socialism with Chinese Characteristics for a New Era-Delivered at the 19th National Congress of the Communist Party of China. 2017. Available online: http:/ / www.chinadaily. com.cn/m/shandong/yantai/2017-11/04/content_34175088.htm (accessed on 21 November 2018).

11. Sun, C.; Tong, Y.; Zou, W. The evolution and a temporal-spatial difference analysis of green development in China. Sustain. Cities Soc. 2018, 41, 52-61. [CrossRef]

12. Swainson, L.; Mahanty, S. Green economy meets political economy: Lessons from the "Aceh Green" initiative, Indonesia. Glob. Environ. Chang. 2018, 53, 286-295. [CrossRef]

13. Merino-Saum, A.; Baldi, M.G.; Gunderson, I.; Oberle, B. Articulating natural resources and sustainable development goals through green economy indicators: A systematic analysis. Resour. Conserv. Recycl. 2018, 139, 90-103. [CrossRef]

14. Pan, W.; Pan, W.; Hu, C.; Tu, H.; Zhao, C.; Yu, D.; Xiong, J.; Zheng, G. Assessing the green economy in China: An improved framework. J. Clean. Prod. 2019, 209, 680-691. [CrossRef]

15. Sharma, M. Development of a 'Green building sustainability model' for Green buildings in India. J. Clean. Prod. 2018, 190, 538-551. [CrossRef]

16. Onuoha, I.J.; Aliagha, G.U.; Rahman, M.S.A. Modelling the effects of green building incentives and green building skills on supply factors affecting green commercial property investment. Renew. Sustain. Energy Rev. 2018, 90, 814-823. [CrossRef]

17. Dwaikat, L.N.; Ali, K.N. The economic benefits of a green building_Evidence from Malaysia. J. Build. Eng. 2018, 18, 448-453. [CrossRef]

18. Dallasega, P.; Sarkis, J. Understanding greening supply chains: Proximity analysis can help. Resour. Conserv. Recycl. 2018, 139, 76-77. [CrossRef] 
19. Tseng, M.L.; Islam, M.S.; Karia, N.; Fauzi, F.A.; Afrin, S. A literature review on green supply chain management: Trends and future challenges. Resour. Conserv. Recycl. 2019, 141, 145-162. [CrossRef]

20. Chen, W. Comparison Between Bibliometric Method and Content Analysis Method. Inf. Sci. 2001, 8, 884-886. (In Chinese)

21. Shiffrin, R.M.; Börner, K. Mapping knowledge domains. Proc. Natl. Acad. Sci. USA 2004, 101, 5183-5185. [CrossRef] [PubMed]

22. Mao, G.; Huang, N.; Chen, L.; Wang, H. Research on biomass energy and environment from the past to the future: A bibliometric analysis. Sci. Total Environ. 2018, 635, 1081-1090. [CrossRef] [PubMed]

23. Wu, F.; Geng, Y.; Tian, X.; Zhong, S.; Wu, W.; Yu, S.; Xiao, S. Responding climate change: A bibliometric review on urban environmental governance. J. Clean. Prod. 2018, 204, 344-354. [CrossRef]

24. Li, J.; Chen, C. CiteSpace: Text Mining and Visualization in Scientific Literature, 2nd ed.; Capital University of Economics and Business Press: Beijing, China, 2016. (In Chinese)

25. Xiang, C.; Wang, Y.; Liu, H. A scientometrics review on nonpoint source pollution research. Ecol. Eng. 2017, 99, 400-408. [CrossRef]

26. Li, X.; Ma, E.; Qu, H. Knowledge mapping of hospitality research-A visual analysis using CiteSpace. Int. J. Hosp. Manag. 2017, 60, 77-93. [CrossRef]

27. Pierpaoli, M.; Ruello, M. Indoor Air Quality: A Bibliometric Study. Sustainability 2018, 10, 3830. [CrossRef]

28. Lin, Z.; Wu, C.; Hong, W. Visualization analysis of ecological assets/values research by knowledge mapping. Acta Ecol. Sin. 2015, 35, 142-154. [CrossRef]

29. Liu, X.; Huang, F.; Wang, P. Principles and Methods of GIS Spatial Analysis, 2nd ed.; China Science Publishing \& Media Ltd.: Beijing, China, 2008. (In Chinese)

30. Marx, K. The Economic and Philosophic Manuscripts of 1844. Economica 1960, 26, 379. [CrossRef]

31. WCED. Report of the World Commission on Environment and Development: Our Common Future. 1987. Available online: http:/ / www.un-documents.net/wced-ocf.htm (accessed on 21 November 2018).

32. Propaganda Department of the CPC Central Committee. General Secretary Xi Jinping's Series of Important Speeches; People's Publishing House: Beijing, China, 2016. (In Chinese)

33. Lesage, J.P.; Pace, R.K. Introduction to Spatial Econometrics; CRC Press: Boca Raton, FL, USA, 2009; pp. 513-514.

34. Dunn, P.J.; Al, E.A.E. Key Green Chemistry Research Areas-A Perspective from Pharmaceutical Manufacturers. Green Chem. 2007, 38, 411-420. [CrossRef]

35. Welch, C.J.; Brkovic, T.; Schafer, W.; Gong, X. Performance to burn? Re-evaluating the choice of acetonitrile as the platform solvent for analytical HPLC. Green Chem. 2009, 11, 1232-1238. [CrossRef]

36. Wang, B.; Wu, Y.; Yan, P. Environmental Efficiency and Environmental Total Factor Productivity Growth in China's Regional Economies. Econ. Res. J. 2010, 5, 95-109. (In Chinese)

37. Bai, C.; Sarkis, J. Green supplier development: Analytical evaluation using rough set theory. J. Clean. Prod. 2010, 18, 1200-1210. [CrossRef]

38. Sarkis, J.; Zhu, Q.; Lai, K.H. An organizational theoretic review of green supply chain management literature. Int. J. Prod. Econ. 2011, 130, 1-15. [CrossRef]

39. Albino, V.; Balice, A.; Dangelico, R.M. Environmental strategies and green product development: An overview on sustainability-driven companies. Bus. Strategy Environ. 2009, 18, 83-96. [CrossRef]

40. Huang, J.; Lv, H.; Wang, L. Mechanism of financial development influencing regional green development: Based on eco-efficiency and spatial econometrics. Geogr. Res. 2014, 33, 532-545. (In Chinese)

41. Li, X.; Pan, J. Compilation of China's Green Development Index_-“2010 China Green Development Index Annual Report-Inter-provincial Comparison". Rev. Econ. Res. 2011, 2, 36-64. (In Chinese) [CrossRef]

42. Li, X.; Liu, Y.; Song, T. Calculation of the Green Development Index. Soc. Sci. China 2014, 6, 69-95. (In Chinese)

43. Chen, S.; Golley, J. 'Green' productivity growth in China's industrial economy. Energy Econ. 2014, 44, 89-98. [CrossRef]

44. Zhap, J. Reconciliation between man and nature: Examining the values of "green development". Philos. Res. 2012, 9, 28-31. (In Chinese)

45. Jiang, N.; Xiang, R. Some problems in the green development of China's economy. Contemp. Econ. Res. 2013, 2, 50-54. (In Chinese) 
46. Hu, A.; Zhou, S. Green Development: Functional Definition, Mechanism Analysis and Development Strategy. China Population. Resour. Environ. 2014, 24, 14-20. (In Chinese)

47. Hu, A. China: Innovative Green Development; Springer: Berlin/Heidelberg, Germany, 2014.

(C) 2018 by the authors. Licensee MDPI, Basel, Switzerland. This article is an open access article distributed under the terms and conditions of the Creative Commons Attribution (CC BY) license (http://creativecommons.org/licenses/by/4.0/). 